\title{
THE CHALLENGE OF FOOD SAFETY FOR HEAD START PERSONNEL
}

\author{
By \\ MARY S. CALLISON \\ Bachelor of Science \\ Oklahoma State University \\ Stillwater. Oklahoma \\ 1977
}

Submitted to the Faculty of the

Graduate College of the

Oklahoma State University

in partial fulfillment of the requirements for the Degree of

MASTER OF SCIENCE

July, 1996 


\section{THE CHALLENGE OF FOOD SAFETY FOR HEAD START PERSONNEL}

Thesis Approved:

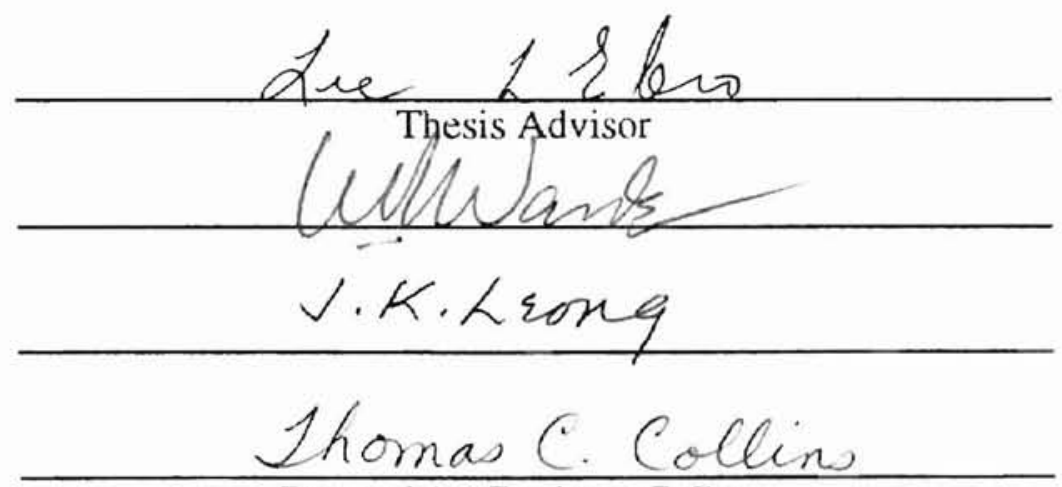

Dean of the Graduate College 


\section{ACKNOWLEDGMENTS}

I would like to express my sincere thanks and gratitude to Dr. Lea Ehro, acudemic and thesis advisor, for her encouragement and support while completing my graduatc work. Dr. Ebro was the key to my return to Oklahoma State University to complete my dietetic internship and graduate degree. She was the first professor at (Oklahoma State University who was really interested in my educational and career goals and made me welcome at this university. I would also like to thank Dr. William Wardc and Dr. Jemold Leong, the other members of my committee for their assistance, suggestions. and contributions. Additionally, I would like to thank Dr. Bernice Kopel for developing my interest in child nutrition.

I would like to thank Kellie Bryant, consultant dietitian for letting me participale in the Head Start Nutrition Conference. The people who attended the conference and participated in this study have my appreciation, along with Clyde Hendersen of Sysco. who provided the snacks. Two other consultant dietitians, Cecelia Schicher and Pam Baggett deserve recognition for heing excellent mentors and role models for me. Also, my high school home economics teacher, Ethyl Outhier deserves acknowledgment for sparking my interest in dietetics.

I am especially grateful to my hushand, Glenn who wholeheartedly supported my continued pursuit of educational and career goals. Without his moral support, patience, and encouragement I would not have been able to complete my internship and graduate studies. And last, but not least, I would like to thank my parents and sisters for instilling in me the love of hooks, lifelong learning and education. I would like to dedicate this thesis to my favorite professor and advisor. Dr. Lei Ehro; my husband, Glenn; my mother. 
Juanita; and my father, Hugh, who died hefore I started this phase of my educational endeavor. 


\section{TABLE OF CONTENTS}

Chapter

Page

I. INTRODUCTION

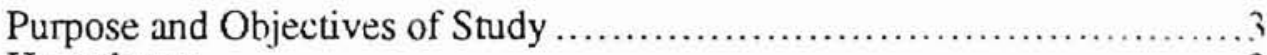

Hypotheses .......................................................... 3

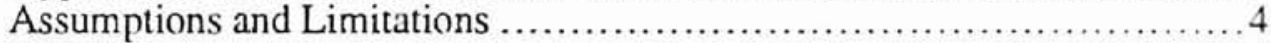

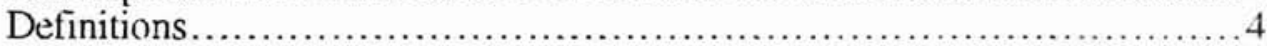

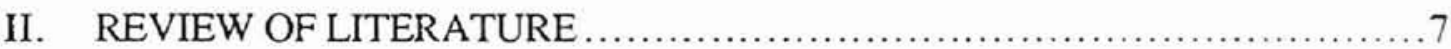

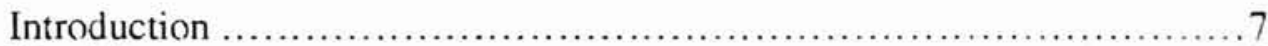

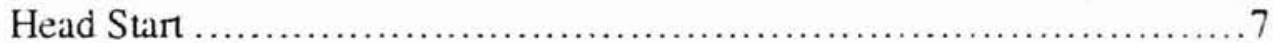

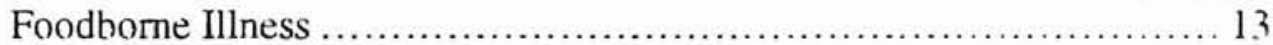

Discussion of Microbiological Hazards ........................ 14

Emerging Pathogens.......................................... 16

Hazard Analysis and Critical Control Points (HACCP) ............... 17

Prevention of Foodhorne Illness Outbreaks ........................... 23

Research in Child Care and Training.................................. 24

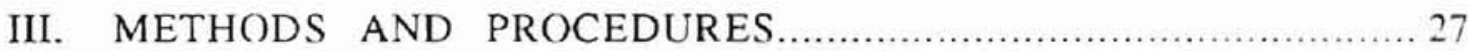

Research Design .................................................. 27

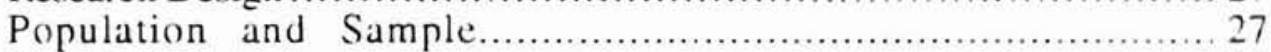

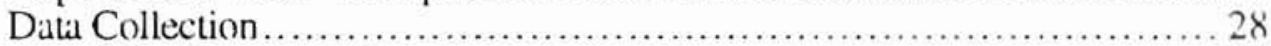

Development of Instrument................................... 28

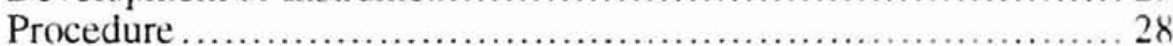

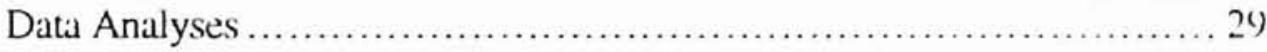

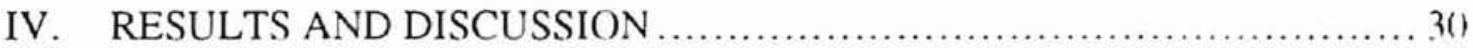

Demographic Charcterisitics....................................... 30

Gender, Age and Location......................................

Education and Type of Training................................. 31)

Foodservice Experience ...................................... 37

Superviosry Responsiblities................................... 37

Attitudes of Participants Toward Standard

Food Safety Practices............................................. 37

Knowledge of Participants Regarding Standard

Food Safety Handling Practices .................................. 39

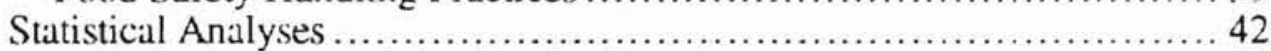

Attitudes Toward Food Safety Practices ........................ 42

Fond Safety Knowledge .......................................... 44

Knowledge and Attitudes .................................... 45 
V. SUMMARY. RECOMMENDATIONS AND IMPLICATIONS 48

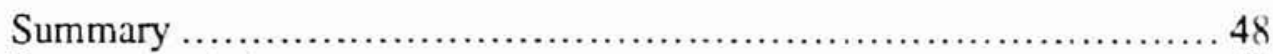

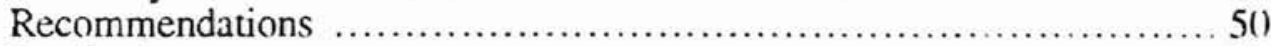

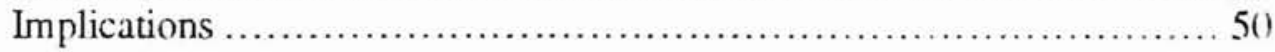

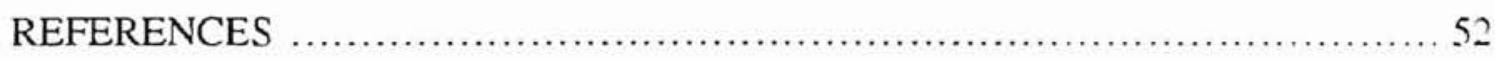

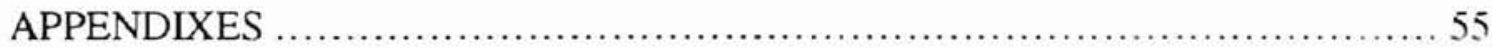

APPENDIX A - COVER LETTER AND QUESTIONNAIRE ............ 56

APPENDIX B - INSTITUTIONAL REVIEW BOARD

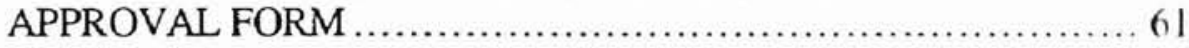

APPENDIX C -TEMPERATURE DANGER ZONE ................... 0,3

APPENDIX D - MICROBIOLOGICAL HAZARDS ..................... 0.5

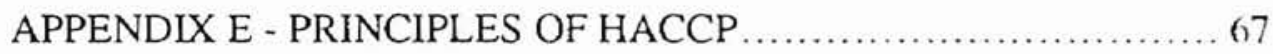

APPENDIX F - CCP DECISION TREE $\ldots \ldots \ldots \ldots \ldots \ldots \ldots \ldots \ldots \ldots \ldots \ldots \ldots \ldots \ldots \ldots \ldots \ldots \ldots$

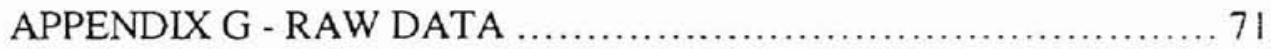




\section{LIST OF TABLES}

Table

I. State Allocation and Enrollment of

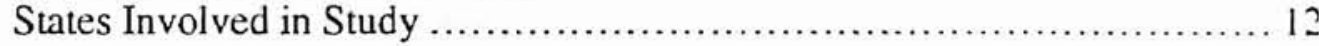

II. Number and Percentage of Subjects

According to Demographic Variables................................ 3 i

III. Attitudinal Responses Toward Food

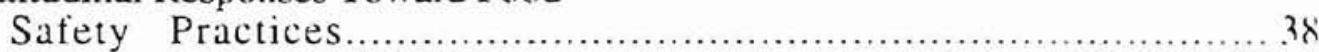

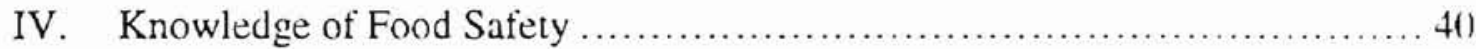

V. Analysis of Variance (ANOVA) for Attitudinal

Practices Ratings and Educational Level

VI. Duncan's Multiple Range Test for Attitudinal

Practice Ratings and Educational Level...................................... 42

VII. T-Test Determination on Attitudinal Practices and

Training and Experience.

VIII. T-Test Determination on Food Safety

Knowledge and Gender

IX. Pearson's Correlation Coefficients Knowledge and Attitudinal Practices

X. Attitudinal Responses Toward

Food Safety Practices............................................. 72

XI. Knowledge of Food Safely Responses ................................ 76 


\section{LIST OF FIGURES}

Figure

Page

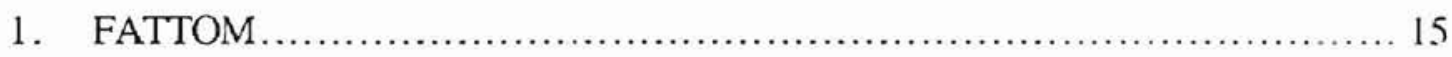

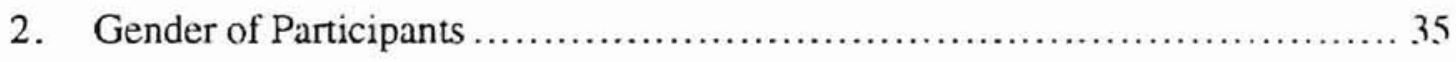

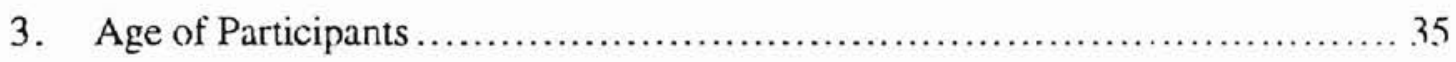

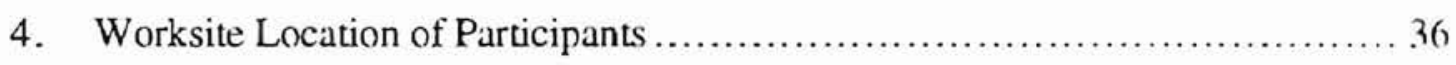

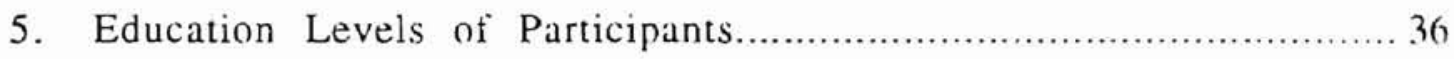

6. Comparison of Knowledge Scores and Attitudinal Practice Ratings ....................................... 46 


\section{CHAPTER I}

\section{INTRODUCTION}

The safety of food consumed by children in today's society is of paramount importance. The outbreak of Escherichia coli 0157:H7 in Northwestern United States in 1993 focused society's attention on the issue of safe food. More than 5(x) lahoratoryconfirmed illnesses and four deaths occurred during this outhreak" (Marks \& Roherts. 1993, p. 1). Food must be safe for consumption, especially food that is caten hy children who are one of society's most vulnerable populations.

In the recently issued 1995 Food Code, the Food and Drug Administration (FDA) stated: "foodborne illness in the United States is a major cause of personal distress. preventable death, and avoidable economic hurden".

An estimated 24 to 81 million people become ill from microorganisms in food, resulting in an estimaled $10,(0)(k)$ needless deaths every year. The annual cost of foodhorne illness is estimated to be hetween $\$ 7.7$ and $\$ 2.3$ billion. Foodborne illness generally causes only lost time from work or discomfort for most victims. For some, especially preschool age children, older adults in health care facilities and those with impaired immune systems, foodhorne illness is more serious and may be life threatening" (Food Code, 1995).

"Food Salety will be the dominant and most thorny issue lacing the industry (foodservice) through the rest of the century" (Martin. 1993, p. 75). Even though there are numerous foodhorne illness outhreaks reported, more oceur that are unreported.

Foodborne illness outhreaks go undocumented because consumers are not aware of the symptoms and incorrectly associate fondhorne illness symptoms with the flu or eolds. The Fond and Drug Administration (FDA) updated the food laws of the United States when it issued the 1993 Fond Code. This was done to ensure that a new model hased on advances in science and reflective of new technologies was in place (Ford Code, 1995). It was 
revised in 1995 to provide further clarification and incorporate the framework for the application of Hazard Analysis and Critical Control Point (HACCP) principles (Food Code, 1995). The 1995 Food Code highlighted the importunce of using a systematic method such as HACCP in order to have adequate controls to prevent foodhorne illnesses in foodservice operations. Training of employees and managers regarding food safety was also stressed as a critical element in the foodservice industry.

Food provided to children should not expose them to an increased risk for foodborne illness due to unnecessary hazardous food practices. Several studies have reinforced the importance of providing sufe food to children. Alhrecht, Sumner \& Henneman pointed out "One incident of improper food handling by a child care provider has the potential of affecting many children who are at risk for foodhorne illnesses" (1992. p. 740). In a study done in Texas, Briley \& Roberts-Gray (1994) stated:

The demand for child care will continue to grow. It is critical that decisions be made that will ensure that the rising numbers of children who rely on the child care system to provide one or more of the daily meals have opportunities to eal nutritious food that keep them from hunger, promote their proper growth and reinforce choices and hahits that are consistent with nutrition principles in the Dietary Gutidelines for Americans" (p. 281).

It is imperative that children's food he safe and wholesome for consumption while promoting their proper growth and development.

Head Start is a child development program, hut must also comply with regulations related to Child Care Centers. The nutrtion component of Head Start is supplemented with funding from the Child and Adult Care Food Program (CACFP) whose regulations also apply to Head Start.

Children who participate in Head Start programs are targeted lor services due to the high risk conditions they experience. Most children enrolled in Head Start are lour years of age and must be economically disadvantaged to qualify. In Marks \& Roherts (199.3) study of costs associated with $E$. colithey assumed that all cases that died or developed severe or chronic illness were four yeurs old at the onset of the illness. This was the average age in a 
Minnesota study of 117 children under age 18 with severe or chronic illness due to $E$. coli 0157:H7. Additionally, other studies identified children under five years old as a risk factor for $E$. coli disease (Marks \& Roherts, 1993, p. 53). Therefore, Head Start enrollees are especially susceptible to $E$. coli due to their age (four years old).

Children enrolled in Head Start usually have other complicating factors such as physical and mental disabilities, barriers to adequate health care. living in single parent homes, educational risk, poor housing conditions and nutrition problems (Administration on Children, Youth and Families, 1995). For these children with special circumstances. Head Start is more than just learning. Its focus is comprehensive and its aim is to make the children socially competent for the future so that they can achieve success, especially in their educational endeavors.

\section{Purpose and Objectives of the Study}

The purpose of this study was to determine the food safety knowledge and attitudinal practices of people working with Head Start programs. The specific objectives included:

1. Identify the food safety knowledge and attitudes towards food salfely of Head Start workshop participants and relate these with selected personal variahles.

2. Determine if their knowledge and attitudinal practices towards ford salety principles conformed with accepted standards.

3. Identify food safety training needs for Head Start Program personnel hased on the results of the study.

Hypotheses

The following hypotheses were examined.

$\mathrm{H}_{0}$ 1. There will be no signilicant associations between food safety attitudinal practices of Head Start workshop participants and selected personal variahles: gender, 
age, education level, training, years of experience, types of operations and supervisory responsibilities.

$\mathrm{H}_{\mathrm{O}}$ 2. There will be no significant associations between food safety knowledge of Head Start workshop participants and selected personal variables as listed in $\mathrm{H}_{0} 1$.

$\mathrm{H}_{\mathrm{O}} 3$. There will be no significant associations between food safety knowledge and attitudinal practices of Head Start workshop participants.

\section{Assumptions and Limitations}

Two assumptions made in this research were:

1. The workshop participants would answer the questionnaire honestly to the hest of their ability.

2. The participants were knowledgeable enough about food safety practices to actually answer the questionnaire.

A major limitation in this study was that only a small sample of Head Start personnel attended the regional nutrition workshop in San Antonio, Texas. The subjects who attended the regional nutrition workshop ranged from Head Start personnel involved with the food preparation and service at local centers, to those responsible for the overall administration of the Head Start Programs in their districts. Even though this was not a random sample, the subjects had diverse backgrounds and worked at locations throughout the Southwest region of the United States.

\section{Definitions}

The following terms were defined so that the researcher's meaning is specifically understood.

"Critical Control Points (CCP) are those processing determiners whose loss of control would result in an unacceptable food safety risk" (Bauman, 1974. p. 3(1). 
Critical Limit, as defined in the Food Code, means the maximum or minimum value to which a physical, biological, or chemical parameter must be controlled at a critical control point to minimize the risk that the identified food safety hazard may occur" (Food Code. 1995, p. HACCP 2).

Cross Contamination is either direct or indirect from a contaminated food to other foods.

a.) "Indirect cross contamination occurs when a contaminated (e.g. raw) food is handled by persons or when it contacts surfaces of utensils or equipment and subsequently the contaminated hands of the person or surface contacts a previously uncontaminated or cooked food. Since cross contamination is a series of sequential events, it occurs over time; hence it is difticult to detect during routine inspections of shor duration or during retrospective epidemiologic investigations“" (Bryan, 1988, p. 669).

b.) Direct Contamination occurs when the contaminated hands of a person handles uncontaminated food or sneezes/coughs directly on the food.

"Fondhome Disease Outhreak is defined as an incident in which 1) two or more persons experience a similar illness after ingestion of a common food, and 2) epidemiologic analysis implicates the food as the source of the illness. A few exceptions exist: for example, one case of hotulism or chemical poisoning constitutes an outhreak" (Centers fior Disease Control. 199(), p. 16).

Fondhorne infections are illnesses "caused by the activity of a large number of hacterial cells carried hy the food into the gastrointestinal system of the victum" (Spears, 1995, $\Gamma$. 426).

Fondhome intoxications are outhreaks of acute gastroenteritis "caused hy toxins formed in the food prior to consumption" (Spears, 1995, p. 426).

"Hazard means a hiological, chemical, or physical property that maly cause an unaceeptahle CONSUMER health risk" (Food Code, 1995, p. 9).

"Hazard Analysis and Critical Control Points (HACCP) is a preventive system for quality control, designed to inform management of potential dangers so that corrective action can be taken; emphasis is on microhiologic control" (Boheng \& David, 1978, p.524). 
Head Start is a federally funded, early child development program. serving low income children and their families. "Head Start was originally designed to serve as a model of comprehensive services including health, education. parent involvement and social services" (National Head Start Association, 1990, p. 34).

"Highly Suscentihle Population means a group of PERSONs who are more likely than other populations to experience foodborne disease because they are immunocompromised or older adults and in a facility that provides health care or assisted living services. such us a hospital or nursing home; or preschool age children in a facility that provides custodial care, such as a day care center" (Food Code, 1995, p. 9).

Potentially Hazardnus Fond means a

(a) FOOD that is natural or synthetic and is in a form capable of supporting:

(i) The rapid and progressive growth of infectious or toxigenic microorganisms;

(ii) The growth and toxin production of Clostridium borulinum; or

(iii) In shell eggs, the growth of Salmonella enteritidis.

(b) Potentially hazardous food includes an animal FOOD (a FOCD of animal origin) that is raw or heat-treated; a FOOD of plant origin that is heal-treated or consists of raw seed sprouts; cut melons; and garlic and oil mixtures.

(c) Potentially hazardous food: does not include:

(i) An air-cooled hard-boiled egg with shell intact:

(ii) A FOOD with a WATER ACTIVITY $\left(\mathrm{AW}\left(\mathrm{A}_{\mathrm{w}}\right)\right)$ value of 0.85 or less:

(iii) A FOOD with a hydrogen ion concentration $(\mathrm{PH}(\mathrm{pH}))$ level of 4.6 or helow when measured at 24"C (75"F);

(iv) A FOOD, in an unopened HERMETICALLY SEALED C(INTAINER that is commercially processed to achieve and maintain commercial sterility under conditions of nonrefrigerated storage and distribution: and

(v) A FOOD for which a variance granted by the REGULATORY AUTHORITY is hased upon laboratory evidence demonstrating that rapid and progressive growth of infectious and toxigenic microorganisms or the slower growth of C. botulinum cannot occur (Food Code, 1995, p. 9).

Virus is defined as "Disease producing agent smaller than the ordinary germ; consists of a nucleic acid, either RNA or DNA, enclosed in a protein layer. It is a living pathogen that can multiply only in the presence of living, healthy host cells" (Claudio \& Lagua, 199)1. p. $245 \& 246)$. 


\title{
CHAPTER II
}

\section{REVIEW OF LITERATURE}

\author{
Introduction
}

A brief historical review of Head Start will be covered in this chapter. Other major areas reviewed encompassed foodborne illness, food safety and other research.

\section{Head Start}

Head Start evolved from the War on Poverty, which was declared hy President Lyndon Johnson in 1964 with the establishment of the Economic Opportunity Act. The Economic Opportunity Act of 1964 had various aspects including: 1) The Joh Corp. whose purpose was to provide education and training for employment. 2) The Community Action Program, whose objective was to mobilize the poor themselves to fight poverty. and 3) VISTA, a domestic Peace Corpss (Zigler \& Valentine, 1979).

By the middle of 1965 , the Office of Economic Opportunity (()E()) had spent approximately $9 \%$ of its $3(x)$ million dollar appropriation with expectations of spending only half by the end of the year (Zigler and Muenchow, 1992). The direcior (1) ()E(). Sergeant Shriver, was concerned ahout utilizing the surplus funds and a study was undertaken hy OEO's research division to investigate the complete problem of poverty and provide recommendations for putting the surplus funding to good use. The research division found that almost half of the nation's 30 million poor people were children. This large number of poor children led Shriver to helieve that it was imperative to do something about children in order to attack the War on Poverty (Zigler \& Valentine, 1979). 
Shriver recalled studies funded by the Kennedy Foundation which showed early intervention with high risk children and their families could raise IQ scores and that good nutrition in early life could affect mental development. When Shriver was President of the Chicago School Board, it came to his attention that children living in the slums had numerous obstacles to face. He thought their chances in life could he greatly improved hy preschool exposure to "books, teachers, desks, pencils, chalk and school huildings" (Zigler \& Valentine, 1979 , p. 53). Shriver's idea was to prepare poor children for lirst grade and provide proper food, immunizations, and medical examinations to uncover hearing and vision problems. By doing, so he hoped to alleviate barriers to learning. Shriver discussed the idea of a preschool program with numerous scientists and experts m children's services, including his family pediatrician, Dr. Rohert Cooke. The experts consulted by Shriver were supportive of the program and Cooke and members of the ()E() staff enlarged the preschool program idea further than an approach hased purcly in academics (Zigler \& Muenchow, 1992). Cooke chaired a Head Start planning committec in December of 1964 and the comprehensive scope of Head Start was determined hy the committee's very composition. The commitlee included two early childhoud educilors. four physicians, a professor of nursing, an associate dean of social work. a nun who was a college president, a dean of a college of education, a clinical psychologist and two research psychologists (Zigler \& Valentine, 1979)

"The fundamental idea tehind Head Start was to get kids ready so they would have a chance in school and a chance in scheol would give them a chance in lili" (Zigler \& Valentine, 1979, p. 59). Head Start was hased on the American Dream--that education is the key to a hetter life. Schort (1988) stated: "By midsummer of" 1965. Head Start was helping half a million poor children and their families--in some measure-- to overcome physical, intellectual, and social impediments to a successtul start at school" (p. I 84). In 1965, Head Start served 561,(K)() children and utilized a hudget of $\$ 96.4$ million dollars for the summer program (Schorr, 1988). 
The success of the Head Star program comes from key requirements huilt into the program such as parent involvement, health professional connection through screenings and examinations, and matching government funds with $25 \%$ in-kind donations of lahor or goods. In addition to preparing children for their educational endeavors. Head Start has a strong guiding principle of training staff and parents. "Head Start has a positive impact on the training and employment of parents and more than one-third of Head Start stafi are current or former Head Start parents" (Administration on Children. Youth and Familic:s. 1994).

Throughout the span of Head Start, less expensive methods were always sought 10 prepare children for school. During the same perind, Sescame Street experienced greal popularity and reached children from all types of backgrounds. When Zigler was asked to utilize Head Start funds to assist with funding Sesame Street, he asked "How long would a poor child have to watch Sesame Street to get his or her teeth filled?" (Zigler \& Muenchow. 1992, p. 165). This comprehensive philosophy, which included aspects of child development besides education, was the element that set Head Start apart from other pre-school programs.

The Head Start of today's world is dramatically difierent than in 1965. The needs of families and children in the 199()'s who live in poverty, are more complicated and urgent than any time previously. The continued need for Head Start still exists hecause the face of poverty has changed to include more single parents as well as increasing numbers of working parents, as shown hy the following data from the Administration on Youth and Families, 1994:

- More than 5 million children under the age of three are in the care of other adults while their parents work.

- One in tour inlants and toddlers under the age of three (nearly 3 million children) live in fumilies with incomes helow the poverty level.

- Children are increasingly likely to live with just one parent, usually the mother; in 1960), fewer than 10) percent of all children under the age of eighteen lived with one parent; hy 1992, almost 27 percent of all children lived with one parent. 
- In 1960, only 5 percent of all births in the United States were to unmarried mothers; by 1990 , the proportion had risen to 28 percent. About every minute, an American adolescent has a baby; every year. about 1 million adolescents become pregnant.

- Today, we also have new knowledge about the services and supports that are most effective in changing long-term outcomes for young children, as well as new knowledge about the importance of the first three years of life (p. 2).

Parent and community involvement represent the comerstone which has made Head Start one of the most successful preschool programs in the country. The major components of Head Start include: (1) education, (2) health, (3) parent involvement, and (4) social services (Novello, 1994). These services are designed to meet the needs of each child, the community, and its ethnic and cultural characteristics. Early identification of health problems is emphasized in Head Start and every child is involved in it comprehensive health program which includes immunizations, medical, dental, mental health, and nutritional services. Parents are involved in every aspect of the Head Start program. Some serve on policy councils. most attend classes and workshops on child development and all receive stalf visits to the home which allow the parents to learn ahout the needs of their children and educational activities that can be accomplished at home (Administration on Children, Youth and Fumilies, 1994).

The emphasis on training of staff and parents developed when Head Start hegan because there was a great need to have stafl who were competent to care for the children involved. From this need emerged the Child Development Assuciate (CDA) credential. at competency based credential (Zigler, 1992, p. 117). Staff at all levels and in all program areas receive training. The Child Development Associate (CDA) program gives professional and non-professional personnel the chance to pursue academic degrees or certification in early childhood education. Currently, there are over 55.())( CDA's in the USA and many have a bilingual specialization.

Volunteers play an essential role in Head Start programs. All kinds of people provide help to local Head Start programs. Volunters assist with: indoor creattve play, transportation, parent education, renovation of centers, and recruitment and instruction of 
other volunteers. "Approximately 1,157,(00) individuals volunteer, and community organizations provide a wide array of services to Head Start, including the donation of classroom space, educational materials, and equipment for children with disabilities" (Administration on Children, Youth and Families, 1994).

Head Start provides an excellent model in focusing attention on the importance of early childhood development. In addition, Head Start provides parents with numerous opportunities to improve their parenting skills and increase their knowledge of child development through training, home visits, workshops, meetings, and service on policy council. The program determines the standard for child development and day care service: encourages expansion of state and local activities for children. and augments the range and quality of services offered to young children and their families.

Project Head Stant has stond the test of time and in the fiscal year 1994. 740.493 children were enrolled and the program with an annual hudget of $\$ 3.3$ hillion dollars. The program provides services to children from hirth through age five and older, and children attend Head Start for a half day or a whole day that corresponds with the local school calendar. Additionally, some children are served in their homes hy the Head Start programs versus attendance at a center.

The majority of children involved in Head Start are four year olds (62\%) with three year olds making up the next largest group (28\%) and live year olds about $7 \%$, while those younger than 3 years of age comprise about $3 \%$ of the remainder of clients. A total of 14,594 million children have heen served hy the program since it hegan in 1965. During the 1993-94 operating period. Head Start programs reported the following :

- $66 \%$ of Head Start families have incomes of less than $\$ 9,(K)()$ per year

- $83 \%$ have yearly incomes of less than $\$ 12,(\%)(\%)$.

- 13\% of the Head Start enrollment consists of children with disahilitics.

- $30.5 \%$ of the staff are parents of cuitent or former Head Start children

- $69 \%$ of the Head Start children are enrolled in the Medicaid/Early Periodic Screening Diagnosis and Treatment (EPSDT) program which pays for their medical and dental services (Administration on Children, Youth and Families, 1995, p. 4). 
Table I details the total dollars allocated for Head Start in fiscal year 1994 to the states involved in this study. Additionally, the number of children enrolled in the program for each state is shown.

\section{TABLE I}

FY 94

\section{STATE ALLOCATIONS AND ENROLLMENT \\ OF STATES INVOLVED IN STUDY}

\begin{tabular}{llc}
\hline Location of Programs & Funding Dollars & Children Enrolled \\
\hline Texas & $\$ 213,394,321$ & 51.521 \\
American Indian* & $\$ 90,793,(174$ & 18.7 .38 \\
Louisiana & $\$ 75,876,2(0)$ & $9,344.4$ \\
Oklahoma & $\$ 39,(073,258$ & 11.165 \\
Arkansas & $\$ 3(1), 718,819$ & 9.065 \\
New Mexico & $\$ 24.240,691$ & 6,397 \\
South Dakota & $\$ 7,984,880(1)$ & $2 .(1) 25$ \\
\hline
\end{tabular}

*Indian Tribal Organizations throughout the United States

(Administration on Youth and Families, 1995, p. $5 \& 6$ )

The average age of the population being served hy Head Start, mostly three and four year olds, are vulnerable to foodbome illnesses because their immune systems are not fully developed. Recognition of the clinical signs of foodhorne illness is essemtial for caregivers of children. These symptoms include diarthea, nauseil. vomiting, and dehydration. The threat of dehydration caused from diarthea and vomiting is of great concern in children since dehydration can occur rapidly and put their life at risk. Selected foodborne illnesses may have exceptionally bad outcomes including organ failure and/or death (Ollinger-Snyder \& Mathews, 1996). Therefore, it is imperative that the stalf providing and serving meals to this highly susceptihle population he knowledgeable and well trained about fond safety and prevention of foodhorne illness. The position of the American Dietetic Association regarding nutrition standards for child care programs was issued in 1986, reaffirmed in 1993, and effective until ()etoher, 1998. The position is 
stated as follows: It is the position of The American Dietetic Association (ADA) that all child care programs should achieve recommended standards for meering children's nutrition and education needs in a safe, sanitary, supportive enviromment that promotes healthy growth and development (Briley \& Roberts, 1994, p. 323). Food that is safe to consume is required for all humans and essential for the growth and development of children. Head Start's purpose is to improve the health and nutrition status of children, and not cause them to suffer due to a foodhome illness.

\section{Foodborne Illness}

"An estimated 24 to 81 million people become ill from microorganisms in ford. resulting in an estimated 10,00() needless deaths every year" (Food Code, 1995. Г. i). The costs of these illnesses are hard to determine but estimates range from $\$ 7.7$ to $\$ 2.3$ hillion dollars (Fond Code, 1995). It is very difficult to put specific value to lives lost when deaths occur due to foodbome illness. Foodservice personnel, especially those who provide food to highly susceptible populations such as children, elderly, and immune compromised people have an immense ohligation to perform their duties in an exceptional manner to prevent foodbome illness. The foodservice workers must he knowledgeable about prevention of fondhome illnesses, committed to serving safe fords, and he responsible in their work habits to avoid the serious consequences of a foodhornc outhreak.

There are different types of hazards that must he prevented from contaminating food. These include: (1) microhiological, (2) chemical and (3) physical hazards. Micrnhiolngical hazards include: (1) Bacteria, (2) Viruses (3) Parasites (4) Fungi (yeasts \& molds). Chemical hazards include: (1) chemicals that contaminate forod products such as detergents, cleaning agents, etc., (2) acidic food in metal lined containers. (3) excessive quantities of additives pesticides, nitrate, and (4) toxic metals, (lead poisoning ). 
Examples of physical hazards are: metal objects, wires, hroken glass, shavings from cans. hair, and dust, or dirt (Byers, Shanklin, \& Hoover, 1994).

\section{Discussion of microhial hazards}

There are four major groups of microbiological hazards, and hacteria, which is the most abundant, is usually divided into pathogens and toxins. Common pathogens include Salmonella, Listeria monocytogenes, and Clostridium perfringens. Some bacteria releascs. toxins. A few well-known toxins are produced by Bacillus cereus and Clostridium botulinum. (Byers, et al., 1994)

Bacteria spreads easily and attaches itself to human hair, skin, scars. under fingernails and on clothing. Bacteria is also present in mucous membranes in the nose, mouth , throat and also in the intestinal tracts of humans and animals. To prevent hackerial growth, various key elements must be controlled or eliminated: (1) oxygen. (2) food. (3) water (moisture), (4) heat/cold (temperature), (5) acidity/alkalinity of environment. (6) time available for reproduction, and (7) presence or absence of inhihitors. The tume between preparation and service is critical hecause that is when contamination usually occurs. Potentially hazardous foods should not remain un the temperature danger zonc (4) to 140$\left.\left.)^{\prime} \mathrm{F}\right)\left(5^{\prime \prime} \text { to } 60\right)^{\prime \prime C}\right)$ for more than four hours during the entire foxdhandling precess" (Armstrong, 1995, p. 17). A representation of the temperature danger zone has heen included in Appendix C (Byers et al., 1994, p. 3(12).

The Servsafe training program developed by the National Restaturant Association uses the acronym FATTOM 10 assist people in remembering the key elements that must he prevented, controlled or eliminated to prevent hacterial growth (Figure 1) (Armstrong. 1995, p. 17). The acronym stands for Food, Acid, Time Temperature, ()xygen, and Moisture (Armstrong, 1995, p. 17). 
These conditions can be remembered by the acronym FAT-TOM:

$\mathrm{F}$

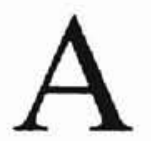

Acidity
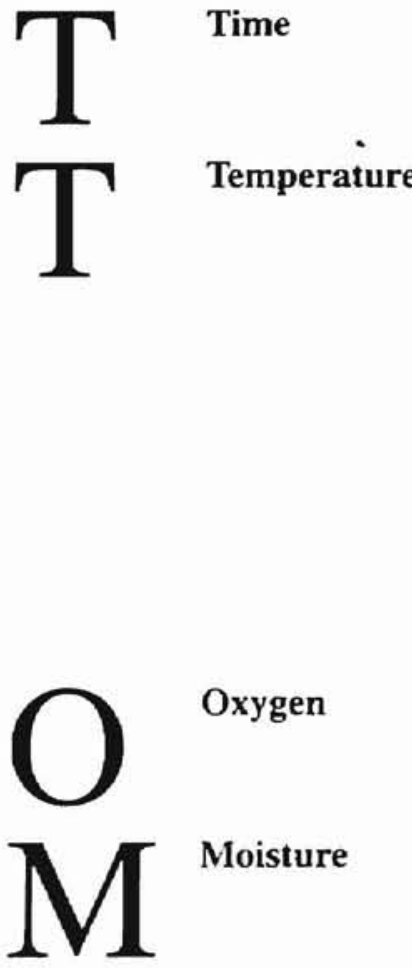

Oxygen

Moisture
High-protein foods are likely to be received already contaminated or may be easily contaminated later.

Acidity is measured on a scale from 0 (very acid) to 14.0 (ver. alkaline [basic]). A solution with a $\mathrm{pH}$ (acid-alkaline measurement) of 7.0 is neutral. Most potentially hazardous foods have a $\mathrm{pH}$ level between $\mathbf{4 . 6}$ and $\mathbf{7 . 0}$ (see Exhibit 2.3). However, high acid foods, such as citrus fruit, rarely allow the growth of harmful bacteria. Adding vinegar or lemon juice to food items will help slow bacterial growth-but it does not ensure control and should not be used as the only defense against bacterial growth.

Potentially hazardous foods should not remain in the temperature danger zone (see Temperature) for more than four hours during the entire foodhandling process.

The temperature danger zone* for potentially hazardous foods is $40^{\circ}$ to $140^{\circ} \mathrm{F}\left(4.4^{\circ}\right.$ to $60^{\circ} \mathrm{C}$ ) (see Exhibit 2.4). However, since bacteria can survive at (and some bacteria can grow at) lower temperatures, refrigerating food is not total protection against bacterial growth. Discard food if it is past its expiration date.

* The FDA's 1993 Model Food Code states that the temperature danger zone is $41^{\circ}$ to $140^{\circ} \mathrm{F}\left(5^{\circ}\right.$ to $60^{\circ} \mathrm{C}$ ). Some health codes specify $45^{\circ}$ to $140^{\circ} \mathrm{F}\left(7.2^{\circ}\right.$ to $\left.60^{\circ} \mathrm{C}\right)$, while other codes use $40^{\circ}$ to $140^{\circ} \mathrm{F}\left(4.4^{\circ}\right.$ to $\left.60^{\circ} \mathrm{C}\right)$ as the temperature danger zone. Check with your local jurisdiction to find out what temperatures are accepted.

Some bacteria require oxygen to grow, while others require no oxygen. However, most of the bacteria that cause foodborne illness can grow either with or without oxygen.

The amount of available water in food is called the water activity $\left(A_{w}\right)$. The lowest $A_{w}$ at which harmful bacteria will grow is $\mathbf{0 . 8 5}$. Most potentially hazardous foods have water activity values of $0.97-0.99$, which is ideal for bacterial growth (see Exhibit 2.5 ). Water activity can be reduced to safer levels by freezing, dehydrating (removing the water), adding sugar or salt, or cooking. Dry foods, such as beans and rice, become potentially hazardous when water is added.

Figure 1: Acronym for Preventing Bacterial Growth (Source: Armstrong. 1995, p. 17) 


\section{Emerging Pathogens}

In the United States, most foodborne illnesses are linked to four widely recognized pathogens: Staphylococcus aureus,Salmonella, Clostridium perfringens, and Bacillus cereus. "Several other pathogens, often referred to as emerging pathogens. have heen identified as important causes of foodborne illness" ( Byers, et al., 1994 p. 3(1)7 ). Those that concern the foodservice industry include: Campylobacter jejuni, Listeria monocytogenes, Norwalk virus, and enterohemorrhagic Escherichia coli ()157:H7. These organisms are usually transported through contaminated water, munure, humans, or they can contaminate food products during processing.

Campylobacter jejuni frequently contaminates food of animal origin hecause it is present in the intestinal tracts of cows, pigs, sheep and poultry. Most outhreaks involving Campylobacter jejuni are caused hy unpasteurized milk or contaminated water. Foodhome outbreaks have also been tied to raw or underconked meat or poultry or heing recontaminated through exposure after conking. $C$. jejuni is susceptihle to heal, acidic conditions, and temperatures helow 3()$^{\prime \prime} \mathrm{C},\left(86^{\circ} \mathrm{F}\right)$, and can he destroyed through proper food handling practices.

"Listeria monocytogenes has been classified as a human pathogen for more than for years. The importance of food as a transmission vehicle has been identilied only in recent years" (Byers, et al., 1994, p. 3(19)). Vulnerable population groups are al high risk for contamination hy this pathogen. It is commonly found in solt cheeses, raw soil-grown vegetables, unpasteurized milk, raw meat and poultry. "Listeria is especially troublesome because it can grow, albeit slowly, at refrigeration temperatures" (Cooke, 199(), p. 792). Good food handling procedures must he adhered to for prevention of outhreaks of L. monocytogenes.

Norwalk Virus is caused hy inlerior personal hygiene hahits ameng lood handlers infected with the virus, which is then transmitted through contaminated water supplies and human contact. It is also found in raw vegetables fertilized with manure, eggs, shellfish. 
coleslaw, frozen foods, and manufactured ice cubes. It does not reproduce in food because it is a virus, but it does remain active. Control of Norwalk Virus is hard to achieve because it withstands freezing temperatures and chlorine sanitizing solution--however, it is susceptible to high temperatures (Byers, et al., 1994).

Enterohemorrhagic Escherichia coli 0157:H7 (E. coli) was tirst identified in 1982 (Byers, et al., 1994). It is a nonspore-forming facultative bacterium and numerous foodrelated outbreaks have been caused by it. The bacteria can cause hemorrhagic colitis (bloody diarrhea) and renal failure (hemolytic uremic symptoms) (Byers, et al., 1994). Foods that have been implicated in the spread of this bacteria include: undercooked or raw ground beef, red meat and unpasteurized milk. To avoid fecal contamination during slaughtering, good food-manufacturing practices should be followed.

Additional emerging pathogens include: Salmonella enteriridis, Vibrio parahaemolyticus and Yersinia enterocolitica. (Byers, et al.. 1994). ()uthreaks involving these particular pathogens are reported less frequently but can also he avoided or significantly reduced if food handlers utilize the proper food handling practices. The 1995 Food Code provided an "assessment of severity of the hiological hazards which may he associated with food being prepared, served, or sold in food estahlishments" ( $P$. HACCP' 6 \& 7). These biological hazards are presented in Appendix D.

Hazard Analysis and Critical Control Points (HACCP)

Hazard Analysis and Critical Control Points (HACCP) is a comprehensive system designed to prevent foodhorne illness outhreaks by examining the total food service operation from procurement through service. HACCP is considered $\mathrm{t}$ he state of the art by regulatory bodies and the fond industry in monitoring and controlling the safety of the food supply. Comprehensive HACCP programs detect critical control points and after identification the hazard can be eliminated or reduced (Fond Code, 1995). 
In a recently released study of the Schwan ice cream outhreak which occurred in 1994 , it was determined that "low-level contamination of foods by salmonella, and thus extremely low infectious doses, can cause disease in humans (Hennessy. Hedherg. Slutsker, White, Besser-Wiek, Moer, Feldman, Coleman, Edmonson, Macdonald,Osterholm \& the Investigation Team, 1996, p. 1285). The researchers additionally state that "many current quality-assurance programs appear to he inadequate in detecting very low levels of contamination" (Hennessy, et al., 1996, p. 1285). They suggest that "improved techniques are needed in the food industry to ensure product safety" (Hennessy, et al., 1996, p.1285).

Bobeng and David statde that the "HACCP system is a preventative program for quality control designed to inform management of potential dangers so that corrective action can be taken" (1977, p. 633). In an earlier publication, Bauman (1974) said that the purpose of developing the HACCP approach was to apply a zero-defects concept (o) production of food, taking into consideration ingredients, processing steps, and potential for consumer abuse (p. 30). Bauman (1974), credited the National Aeronautics and Space Administration (NASA), The Pillshury Company, and the U. S. Army Natick Lahoratories for the development of the HACCP concept.

In HACCP models for foodservice systems, four critical control points have heen distinguished: (1) ingredient control and storage, (2) equipment sanitation, (3) personnel sanitation, and (4) time-temperature relationships. The 1995 Food Code lists seven major principles of HACCP. They are: (1) hazard analysis (2) identily the critical control points in food preparation (3) estahlish critical limits for preventive measures (4) establish procedures to monitor critical control points (5) establish the corrective action to he taken when monitoring shows that a critical limit has been exceeded (6) estahlish eflective record keeping systems that document the HACCP system and (7) estahlish procedures to verily that the HACCP system is working (Appendix E) (Food Code, 1995. p. HACCP 5-

\section{HACCP 23)}


Control of ingredients is achieved through specifications that state the desired sensory characteristics and quantity of the food item, and the microbiological count. Specifications may also cover the type of packiging and time-temperature parameters during transportation. All food must be procured from supplier who are in total complianci with laws related to food, food labeling and distribution.

Upon delivery of food, meticulous inspections should be conducted to ensure compliance with food specifications. Provisions should he visually checked. counted. and weighed. Additionally, food temperatures of refrigerated and frozen food should he recorded. Any items that do not meet specifications should be rejected. Frozen and refrigerated items should he stored promptly under suitable conditions.

Proper care during food storage prevents or controls loss or waste due to deterioration or infestation. Ingredients must be checked frequently to detemine if quality had deteriorated or microbial spoilage has occurred. Appropriate temperature-time relationships during storage are also necessary. Dry goods should be protected from infiltration from insects and rodents and bacterial contamination. The dry storage areas should he at 5()"F to $7(1) \mathrm{F}$ (10)"C to $211^{\circ} \mathrm{C}$ ), well-ventilated, and dry (Byers, et al. 1994).

Temperatures of fond requiring refrigeration and considered to he polemtally hazardous should he $41^{\prime \prime} F(5 " \mathrm{C})$ or helow (Food Code, 1995 p. 57). Accurats thermometers must be utilized in relingeration/freezer units. Additionally, foodservice stafl need to be diligent in preventing cross-contamination of raw and cooked food during refrigerated storage. Frozen foods must he stored at 0$)^{\prime \prime} \mathrm{F}\left(-18^{\prime \prime} \mathrm{C}\right)$ or helow and slould he packaged in materials which are impermeahle to moisture and oxygen (Byers el al., 1994).

Inadequate equipment sanitation and cross contamination were reported by Bryan (1994) as two major factors contributing to foodhorne discase outhreaks. In many outbreaks of foodhorne illness, the sinks, knives, cutting hoards, and hands were common links between contaminated fresh foods and cooked food. 
Where food is handled, the personal sanitation of those working with the food is a critical control point. Handwashing has been an effective way to prevent contamination and the 1995 Food Code stated:
Handwashing
Food employees shall clean their hands and exposed portions of their arms with a cleaning compound in a lavatory that is equipped as specified ... by vigorously rubbing together the surfaces of their lathered hands and arms for at least 20 seconds and thoroughly rinsing with clean water. Employees shall pay particular attention to the area underneath the fingernails and between the fingers Additionally it listed specific times when hands should be washed and required washing hands twice after using the restroom (p. $27 \& 28$ ).
(A) Food employees shall wash their hands as specified under section 2-301.12 and 2-301.13.
(B) Except when washing fruits and vegetables as specified under section 3-302.15, food employees may not contact exposed, ready-to-eat-food with their hare hands and shall use suitable utensils such as deli tissue, spatulas, tongs, single use gloves or dispensing equipment.
(C) Food employees shall minimize bare hand and arm contact with exposed food that is not in a ready-to-eat lom.

\section{Single -Use Gloves}
If used, single-use gloves shall be used for only one task such as working with ready-to-eat food or with raw animal food. used for no, other purpose, and discarded when damaged or soiled, or when interruptions occur in the operation (p. 48).

\section{Hair Restraints}
Food employees shall wear hair restraints such as hats, hatr coverings or nets. heard restraints, and clothing that covers hody hair, that are designed and worn to effectively keep their hair liom contacting exposed tood: clean equipment, utensils, and linens: and unwrapped single-service and single-use articles $(\Gamma, 30) \& 31)$.

People may contaminate the food directly or indirectly. "For each year from 1983 to 1987. the most commonly reported food-preparation practice that contributed to foodhorne disease was improper storage or holding temperature, followed hy poor personal hygiene of the food handler" (Centers for Disease Control, 199() p. 2.3).

Ahuse of the of the time-temperature relationships in ford handling have frequently contributed to foodhome disease outhreaks (Bryan, 1974). Some lactors that have heen identified are inadequate refrigeration, preparing loods far in advance of planned service with improper storage during the interval hefore serving. inadequate heat processing, and 
holding foods in warming devices at temperature that favor bacterial growth. The

following standards regarding temperature and time were taken from the 1995 Food Code:

\section{RECEIVING}

Refrigerated, potentially hazardous food shall be at a temperature of 5 C

$\left(41^{\circ} \mathrm{F}\right)$ or below when received ( p. 37).

THAWING

Potentially hazardous food shall be thawed:

(A) under refrigeration that maintains the food temperature at 5 "C

(41"F), or below;

(B) Completely submerged under running water

(1) at a water temperature of $21^{\circ} \mathrm{C}\left(70^{\circ} \mathrm{F}\right)$ or helow;

(2) With sufficient water velocity to agitate and 17oat off loose particles in an overflow and

(3) For a period of time that does not allow thawed portions of ready-to-eat food to rise above $5^{\circ} \mathrm{C}\left(41^{\prime \prime} \mathrm{F}\right)$, or

(4) For a period of time that does not allow thawed portions of a raw animal food requiring cooking ...10 be ahove 5 " C $\left(41^{\circ} \mathrm{F}\right)$ for more than 4 hours including the time the food is exposed to the running water and the time needed lor preparation for cooking or the time it takes under refirigeration to lower the food temperature to $\left.5^{\prime \prime} \mathrm{C}(4)^{\prime \prime} \mathrm{F}\right)$ (p. $57 \& 58$ ).

COOKING (3-401.11)

Except as specified in B and $C$ of this section, raw animal foods such as eggs, fish, poultry, meat and foods containing these raw animal foods, shall he cooked to heat all parts of the fond to a temperature and $f(r$ a time that are at least:

(1) $6.3^{\circ} \mathrm{C}\left(145^{\circ} \mathrm{F}\right)$ or above for 15 seconds for

(a) Shell eggs that are broken and prepared in responsc 10 al consumer's order and lor immediate service, and

(b) Fish and meat that are not specilied in Subparagraph (A) (2) ol this section:

(2) For pork, and exotic species of game animals, comminuted lish and meats (comminuted means reduced in size hy methods including chopping, tlaking, grinding, or mincing- p. 3). injected meats, and eggs that are not prepared as specified in Subparagraph (A) (1) (a) of this section, 68"C (155"F) lior 15 seconds or the temperature specified in 3-4()1.12 that corresponds to the cooking time.

(3) As specified in section 3-4()1.14 (table on p. 54 of ly95 Fond Code) for roasts of heef and corned heef; or

(4) $74^{\prime \prime} \mathrm{C}\left(165^{\prime \prime} \mathrm{F}\right)$ or ahove for 15 seconds for wild game animals as specified in Subparagraphs 3-2()1.17 (C) and (D), poultry. stuffed tish, stufled meat. stulfed pasta, stulfed poultry, or

REHEATING stuftïng containing lish, meat, or poultry.

Potentially hazardous fond that is cooked, cooled and reheated for hor holding shall be reheated so that all parts of the food reach a temperature of at least $74^{\prime \prime} \mathrm{C}\left(165^{\prime \prime} \mathrm{F}\right)$ for 15 seconds. COOLING

(A) Cooked potentially hazardous food shall he cooled:

(1) From 6(l)"C (140"F) to $21 \mathrm{C}\left(7()^{\prime \prime} \mathrm{F}\right)$ within 2 hours: and 
(2) From $21^{\circ} \mathrm{C}\left(70^{\circ} \mathrm{F}\right)$ to $5^{\circ} \mathrm{C}\left(41^{\circ} \mathrm{F}\right)$, or below, within 4 hours.

(B) Potentially hazardous food shall be cooled to $5^{\circ} \mathrm{C}\left(41^{\circ} \mathrm{F}\right)$ or below within 4 hours if prepared from ingredients at ambient temperature, such as reconstituted foods and canned tuna.

(C) A potentially hazardous food received in compliance with laws allowing a temperature above $5{ }^{\circ} \mathrm{C}\left(41^{\circ} \mathrm{F}\right)$ during shipment from the supplier shall be cooled to $5^{\prime \prime} \mathrm{C}\left(41^{\prime \prime} \mathrm{F}\right)$ or below within 4 hours (p. 58).

The temperature of entrees during hot holding in the conventional cook serve system should be at least $\left.60^{\circ} \mathrm{C}(140)^{\prime \prime} \mathrm{F}\right)$. "Temperature measuring devices (such as thermometers or thermocouples) shall be calibrated in accordance, with manufiacturer's specifications as necessary to ensure their accuracy." The storage facility for hot holding must be equipped with an accurate food thermometer. "Since hot holding equipment is designed to maintain rather than increase temperature of fond, entree temperature should he higher than $60 " \mathrm{C}(140 " \mathrm{~F})$ at the onset of hot holding" (Boheng \& David, 1977, p. 6.36). Bryan, (1990) discussed that "failures to hold foods hot have frequently contrihuted to outbreaks of foodborne disease in foodservice establishments and are a great potential for causing outbreaks in fast-fond restaurants, cafeterias, and food-market delis where cooked foods are held hot, or sometimes only warm, for long duration" ( $p .981$ ).

It was emphasized by Peterson and Gunnerson (1974) that results of' microbiological analyses are obtained too late to be useful for the lot heing tested. They also stressed the importance of anticipating and preventing microhiological prohlems in the HACCP system and "stated that much of in-process control consisted of maintaining timetemperature standards and may involve continuous surveillance" (p. 4.3).

The future holds faster techniques for detection of microhiological hazards. These techniques, instruments and systems either complement traditional methods or replace current systems with rapid detection of microorganisms. "Several commercially available instruments and systems are designed to simplify conventonal culturing techniques" (Giese, 1995, p. 64). Two rapid detection tests that have heen researched include PATHSTIK for the detection of Salmonella (Brinkman, Van Beurden, MacKintosh \& Beumer. 
1995) and Dynabeads Anti-Salmonella (Holt, Gast \& Greene, 1995, p. 967). Improved monitoring for foods using time-temperature strips is another technological advance that can aid foodservice operators.

When putting a HACCP system to work, inspection of critical control points (CCP's) needs to be documented. A decision tree has been included in Appendix F to verify which food preparation steps should be designated as CCPs (Appendix F). The foodservice administration of the future may be required to file reports of food safety selfinspection with state or local regulatory officials. Inspections may he hased on the HACCP plan and monitoring it's implementation.

\section{Prevention of Fondhorne Illness Outhreaks}

The avoidance of foodborne illness outbreaks is essential in order to prevent sickness and death especially among vulnerable population groups. Costs associated with foodborne illness are hard to determine accurately. Marks and Roberts reported that USDA's Economic Research Service (ERS) estimated the medical costs and productivity losses from E. coli $\mathrm{O} 157: \mathrm{H} 7$ to range from $\$ 216$ million $\mathrm{to} \$ 580$ million annually (1993. $\mathrm{p}$. 52). "This places it as the fourth most costly foodhome diseases for which the EPS has estimated costs, hehind one parasite (Toxoplasma gondii) and two hactera (Salmonella and Campylobacter)" (Marks \& Roherts, 1993, p. 52).

Managers and foodservice persomel must he diligent in preventing foodhome disease outbreaks in order to maintain a good image among the clients and community they serve. One of management's key functions is to ensure that all staff are adequately trained in safe food handling and preparation (Ollinger-Snyder \& Matthews, 1996). All individuals who are involved in food service must possess enough self discipline to apply the correct food handling practices at work. A person who accepts a position in foodservice has an important ohligation to handle and prepare food appropriately. 
Management must convey the importance of food safety systems like HACCP to employees and make their continued employment dependent upon following correct procedures in handling and monitoring foods and food preparation and service. Every foodservice operation needs a program in place to keep current with new knowledge. especially regarding emerging pathogens, and to ensure that staff employed under their jurisdiction are also kept updated. Re-training and educating fondservice workers is a continuous process. Re-certification with the health department or a course like Scrvesali is essential for foodservice workers (Ollinger-Snyder \& Matthews, 1996).

\section{Research in Child Care}

The people who work in Head Start range from parents of children enrolled to highly trained and educated professionals. Parents of Head Start enrollees make up approximately one-third of the stali. Paraprofessionals or professionals fill the remainder of the positions. Head Start promotes training, and so most staff have training regarding child development and other areas pertinent to children. Volunteers expand the work force of Head Start allowing the staff more freedom to ensure high quality in the program.

Manning (1994) compared the knowledge and attitudes ol loodservice workers who worked in either institutional or temporary food service lacilities. Manning (1994) found significant differences hetween the two groups. Her research indicated that foodservice workers from institutions appeared to have better understanding of safe food handling than those employed in temporary foodservice operations .

Management must he totally supportive of serving safe food in order for employees to buy into producing sale food. Training and education of food service workers is a key function of management. In a study hy Pond-Smith, Richar\% \& Gonzalez., (I992) it is stated:

"The higher percentage of administrators and teachers involved in foodservice indicates that many staff are not trained in food service yet carry out tasks related to fond as secondary assignments of their johs. Non foodservice stafl may lack hoth knowledge and eommitment to 
quality food service and this may contribute to problems in nutrition. sanitation and foodservice management p. 484)."

Pond-Smith, et al. (1992) also emphasized that food quality in child care centers can be improved if all fondservice operations were under the direction of qualitied. well-trained people.

A variety of training methods should be employed when presenting food safety information since many view the subject as dull. Sample case study investigations where foodservice workers act as the investigators could motivate them to higher standards of practice. Additionally, the involvement of trainees in activities increases their ability to perform adequately. One method that has been successiul is using a product called Glo Germ to demonstrate adequate hand washing (Albrecht, et al., 1992, p. 741). Kendrick (1992) reported having good results using “...Glo-Germ, a suhstance that simulates gems on hands and surfaces" (p. 1109). Workshop participants "see the 'germs' left on their hands, in the webs of their fingers, under their jewelry, and on the hacks of their hands and wrists after they wash their hands improperly" (Kendrick, 1992, p. 11(19). The Glo-Gem experience was carried out with great success during the regional Head Start nutriition workshop where this research was conducted.

The importance of providing sale food must he emphasized to workers in foodservice, especially the possibilities of loss of life and loss of reputatom in the community. Once a fond service establishment's reputation is tamshed hy an ill-fated foodhorne illness outhreak, repairing its status in a community can he very difficult. Waites and Arbuthnol (199()) stated: "Unsafe food has to he withdrawn from sale and destroyed, and adverse publicity can lead to further economic loss, closure, law suits, and prosecution. Loss of confidence in a certain food or producer can he long term" ( $९ .722$ ). Therefore, if the facility does not have an adequate number of customers. clients, residents, or patients, the worker may lose his or her joh.

Fond that is sale to consume is usually of high quality hecause people who are dedicated to preparing safe food tend to prepare food correctly. Therefore. commitment to 
produce high sensory quality products coincides with following safe food handling practices.

Foodservice workers must be motivated to practice what they know. This requires self-discipline and continual adherence to excellent food safety practices. Management and employees alike must remind themselves of correct practices and they must see food safely as an important issue affecting their continued employment with the organization. "In general, the difficulties associated with foodhorne illness can be overcome provided that our monitoring systems give us an early warning, that our basic science gives us sufficient understanding of the organism or the toxin, and that our control and education system can react quickly enough" (Waites \& Arbuthnott, 199(), p. 725).

Experts who have written ahout Head Start emphasize that well qualified staff are the necessary ingredients for program success. Additionally, it is emphasized that staft in early childhood development programs and day care staff need adequate compensation. The future of our society depends on children and yualitied personnel need to he recruited and retained to provide effective services.

The nutrition component of Head Start is important hut sometimes it dees not receive adequate attention. Food safety is an afterthought, if that. and some days the program operations are hectic and managed in a haphazard manner. Therelore, it is imperative to employ people with food service expenence or hackground and tuan them appropriately to produce the lood for Head Start enrollecs. Additionally. Head Start administrators need to tike an interest in the nutrition component to ensure sale, attractive food is served to young children. 


\section{CHAPTER III}

\section{METHODOLOGY}

This chapter includes the research design, population and sample, data collection including instrumentation and procedure, and data analysis. Data collection was conducted and completed at a regional Head Start Nutrition workshop.

\section{Research Design}

The research design used in this study was a status quo survey in the form of a personally distributed questionnaire. "A status quo survey is used in research to describe. analyze, and interpret conditions that exist (Best, 1981). Surveys are used for estahlishing associations among variables and providing baseline data (Monsen, 1992). The purpose of this status quo survey was to identify and examine attitudes and knowledge ahout food safety held by Head Start workshop purticipants.

The dependent variahles of this study were knowledge and attitude scores of Head Start workshop participants. The independent variables were selected personal characteristics of the participants.

\section{Population and Sample}

The population in this study included all personnel in Head Start programs in Texas, Oklahoma, New Mexico, Louisiana, Arkansas, and South Dakota whosc sponsoring agencies included school districts, private non-prolit organizations, and Indian Tribal Organizations. The research sample consisted of all invited participants who attended the Head Start Nutrition workshop at San Antonio, Texas, during the spring of 
1995. The questionnaires were distributed to all individuals attending the conference.

Guidelines of the Oklahoma State University Institutional Review Board were followed and approval was secured from this group for the study. Participation in this study was voluntary.

\section{Data Collection}

\section{Development of Instrument}

The research instrument (Appendix A) was adapted from a questionnaire developed and tested by Manning and Snider in 1993. Since the questionnaire had heen used previously, the content, validity, clarity, and format were approved by the research committee of the researcher and a panel of fondservice management professionals. Appropriate corrections and additional questions were incorporaled anto the questionnairc.

The instrument was divided into three sections. Section I included food handling practices and attitudes towards cross contamination, cooling and reheatung. personal hygiene, and temperature control. Section II contained questions ahout food saliely knowledge, personal hygiene and temperature control. Section IIl covered demographic variables of the workshop participants.

\section{Procedure}

The questionnaire contained a cover letter (Appendix A) to describe the research and provided instructions for completion of the questionnaire. The reseacher also announced that healthy snacks would be provided to workshop participants for their assistance in the study. Subjects were assured that names would not he associated with individual questionnaires and data collected would he analyzed as a composile result. Questionnaires were distrihuted in person hy the researcher on March 1, 1995, at a Head Start Nutrition workshop in San Antonio, Texas. The participants were asked to complete the questionnaires and give them to the researcher. Correct answers to the surveys were then 
provided to study participants as part of the training received at the workshop because they requested the information.

\section{Datil Analysis}

The questionnaires were coded and tabulated for analysis. The data were then entered and transferred into the computer using the PC File Software Program (Buttonware, 1985). Standard statistical procedures were used to analyze data (Statistical Analysis System, 1985). Frequencies and percentages used were computed to descrite the demographic variables while t-tests, Analysis of Variance (ANOVA), Duncan Multiple Range Tests and Pearson's $r$ were used to test the hypotheses in this study. Significanco level were established at $\mathrm{p} \leq 0 .(15$, unless otherwise specified by the rescarcher. 


\section{CHAPTER IV}

\section{RESULTS AND DISCUSSION}

This study determined if the attitudes and knowledge toward standard foud handling practices of Head Start personnel were associated with the demographic variahles gender, age, location, education, training, other work experiences, years in food service, and supervision of foodservice workers. Data were obtained from the questionnaire described in Chapter III. The questionnaire was handed out to 74 Head Start nutrition conference participants and 68 were returned for a total response rate of $92 \%(n=68)$.

\section{Demographic Characteristics}

\section{Gender, Age, and Locution}

Females made up the majority of study participants. $85 \%(n=58)$ (Table II and Figure 2). Age categories ranged from under 25 to 55 and older. Almost three-fourths $(n=47)$ of the study participants were over 35 with the remainder, age 34 or less (Table Jl and Figure 3). Participants were from six diflerent states. Texas participants represented about $45 \%(n=29)$ of the group, with $35 \%(n=23)$ coming from ()klahoma. The remaining subjects were from New Mexico, Louisiana, Arkansas and South Dakota (Tahle II and Figure 4). The group represented various cultures including Native Americans, Hispanics. Blacks, Asian Americans and Cauciasians hut an exact hreakdown hy ethnicity was not obtained. 


\section{Education and Type of Training}

Training in safe food preparation and serving were most frequently ohtained through a course provided by the local health department, formal classes on the joh. on the job training by supervisor and through college courses. Except for the local health department course, the types of training were similar to those reported hy Manning (Manning, 1994). Training given by coworkers on the job, or courses through areal vocational technical schools or via correspondence were pathways where food safety information were obtained (Table II).

\section{TABLE I}

\section{NUMBER AND PERCENTAGE OF SUBJECTS ACCORDING,} TO DEMOGRAPHIC VARIABLES

$$
\mathrm{N}=68
$$

\section{DEMOGRAPHIC VARIABLES}

\section{GENDER}

Female

Male

Missing

Total

AGE

Below 25

25-35

$35-44$

45-54

55 and over

Missing

Total

\section{LOCATION}

Texas

Oklahoma

New Mexico

Louisiana

Arkansas

South Dakota

Missing

Total
Freyuency

58

9

1

68

5

14

22

16

9

2

68

85

1.3

$\frac{1}{(1)}$

\section{Percentage}

32.4

23.5

13.2

$\underline{2.9}$

(9). 9

$3 \quad \underline{4.4}$

68 
TABLE II continued

NUMBER AND PERCENTAGE OF SUBJECTS ACCORDING

TO DEMOGRAPHIC VARIABLES

$\mathrm{N}=68$

\begin{tabular}{lrr}
\hline DEMOGRAPHIC VARIABLES & Frequency & Percentugci \\
\hline EDUCATION LEVEL & & \\
Less than High School & 1 & 1.5 \\
High School & 15 & 22.1 \\
College or other & 25 & 36.8 \\
College & 19 & 27.9 \\
MS or Ph.D. & 4 & 5.9 \\
Missing Data & 4 & 5.9 \\
Total & 68 & $1(1)(1)$ \\
& & \\
& & \\
TYPE OF TRAINING * & & 4.3 .3 \\
Local Health Department course & 26 & 38.3 \\
Formal class-OJT & 23 & 36.7 \\
OJT/Supervisor & 22 & 3.5 .1 \\
College course & 21 & 23.3 \\
OJT/Co-worker & 14 & 8.3 \\
CDM - Level 3 & 5 & 5.11 \\
Correspondence & 3 & $5.1)$ \\
CDM - Level 1 & 3 & 1.7 \\
CDM - Level 2 & 1 & 1.5 \\
None & 1 & \\
\hline
\end{tabular}

*Multiple answers were allowed to be chosen 
TABLE II continued

NUMBER AND PERCENTAGE OF SUBJECTS ACCORDING TO DEMOGRAPHIC VARIABLES $\mathrm{N}=68$

\begin{tabular}{|c|c|c|}
\hline VARIABLE & Frequency & Percentage \\
\hline \multicolumn{3}{|c|}{ YEARS OF EXPERIENCE - HEAD START } \\
\hline 0 & 10 & 14.7 \\
\hline $1-9$ & 23 & 3.3 .8 \\
\hline 10 or more & 8 & 11.8 \\
\hline Missing Data & $\underline{27}$ & 39.7 \\
\hline Total & 68 & $1(1)(1)$ \\
\hline \multicolumn{3}{|c|}{ EXPERIENCE - OTHER FACILITIES } \\
\hline Yes & 32 & 47.1 \\
\hline No & 22 & 32.4 \\
\hline Missing Data & $\underline{14}$ & $\underline{2016}$ \\
\hline Total & 68 & 100.1 \\
\hline \multicolumn{3}{|c|}{ YEARS OF EXPERIENCE - OTHER FACILITIES } \\
\hline 0 & 4 & 5.9 \\
\hline $1-9$ & 16 & 23.5 \\
\hline 10 or more & 1.3 & 19.1 \\
\hline Missing Data & 3.5 & 51.5 \\
\hline Total & 68 & $10(1) .0$ \\
\hline
\end{tabular}


TABLE II continued

NUMBER AND PERCENTAGE OF SUBJECTS ACCORDING

TO DEMOGRAPHIC VARIABLES

$\mathrm{N}=68$

\begin{tabular}{lcc}
\hline DEMOGRAPHIC VARIABLES & Yes & Percentage \\
\hline & & \\
OPERATIONS WHERE EXPERIENCE WERE & OBTAINED* \\
Commercial Restaurant & 16 & 35.5 \\
Church & 14 & 31.1 \\
Hospital/Nursing Home & 12 & 26.7 \\
School/College & 11 & 24.4 \\
Government Nutrition Program & 11 & 24.4 \\
Other & 5 & 11.4 \\
Fraternal/Service & 4 & 8.9 \\
Military Foodservice & 4 & 8.9 \\
& & \\
SUPERVISION OF PERSONNEL & & 58.8 \\
Yes & 40 & 27.9 \\
No & 19 & 13.2 \\
Missing Data & $\frac{9}{(9) .9}$ \\
Total & 68 & \\
\hline
\end{tabular}

*multiple answers were allowed to be chosen 


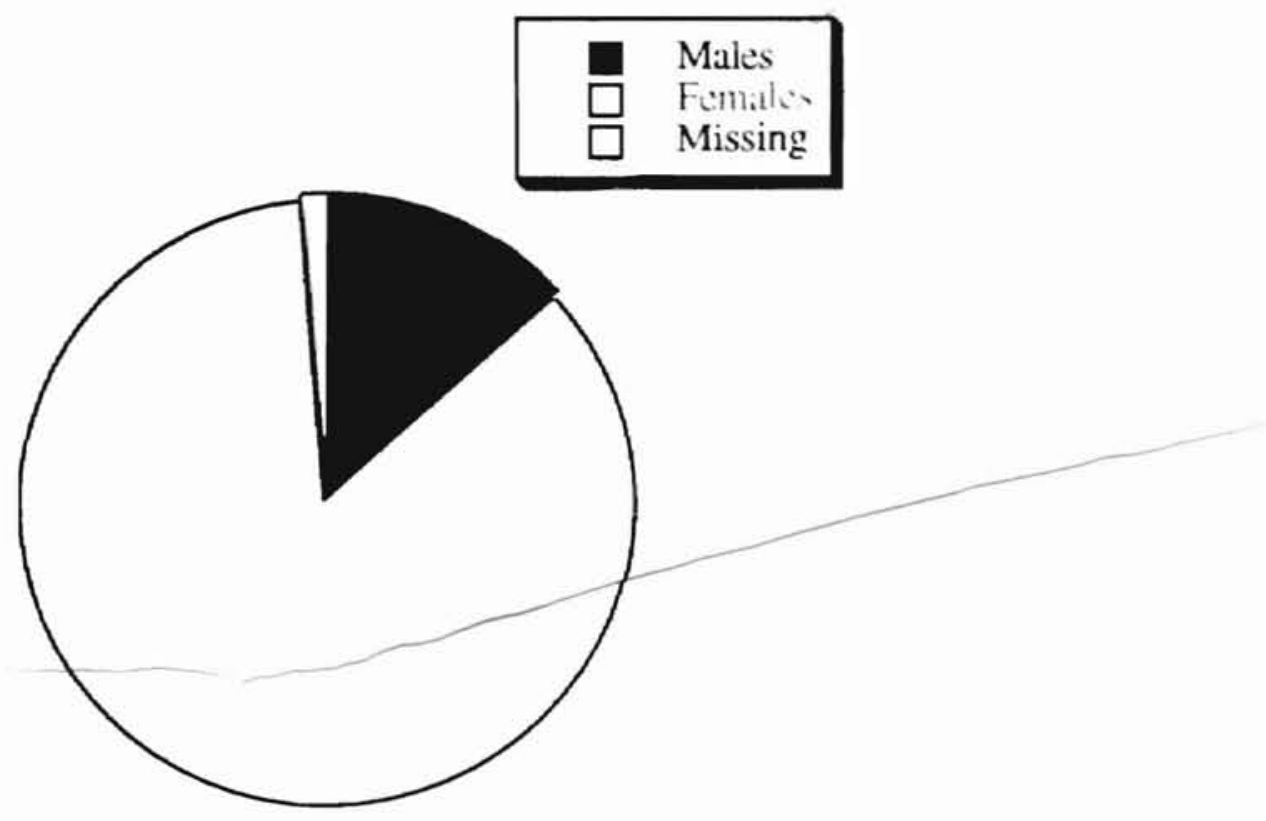

Figure 2: Gender of Participants

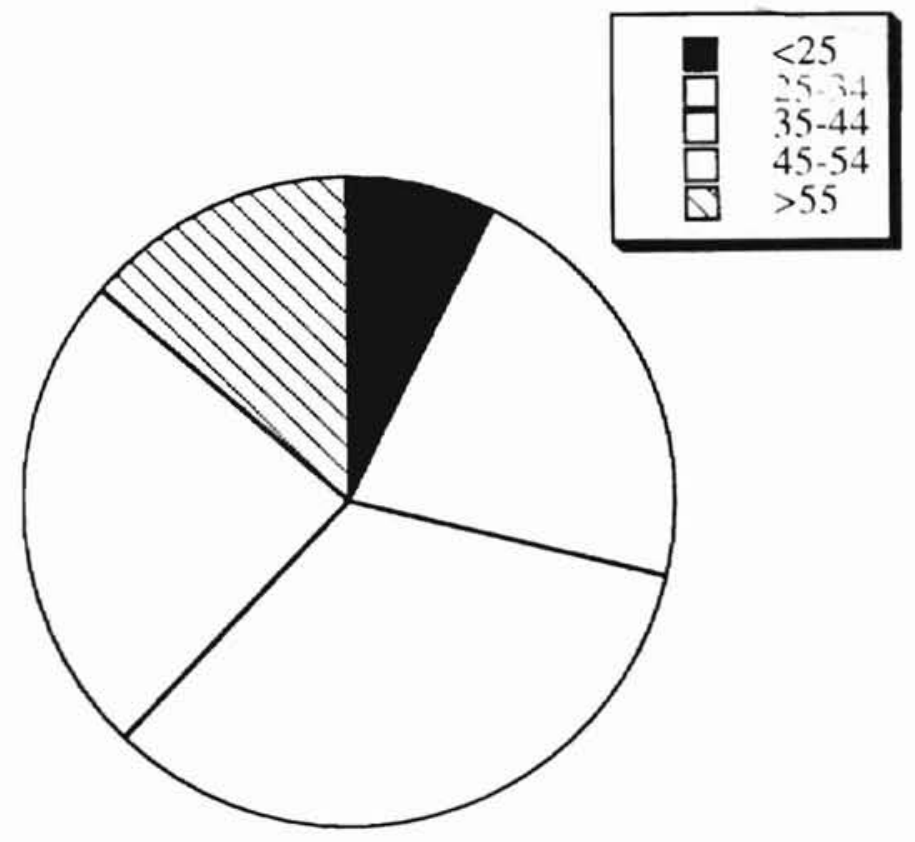

Figure 3: Age of Participants 


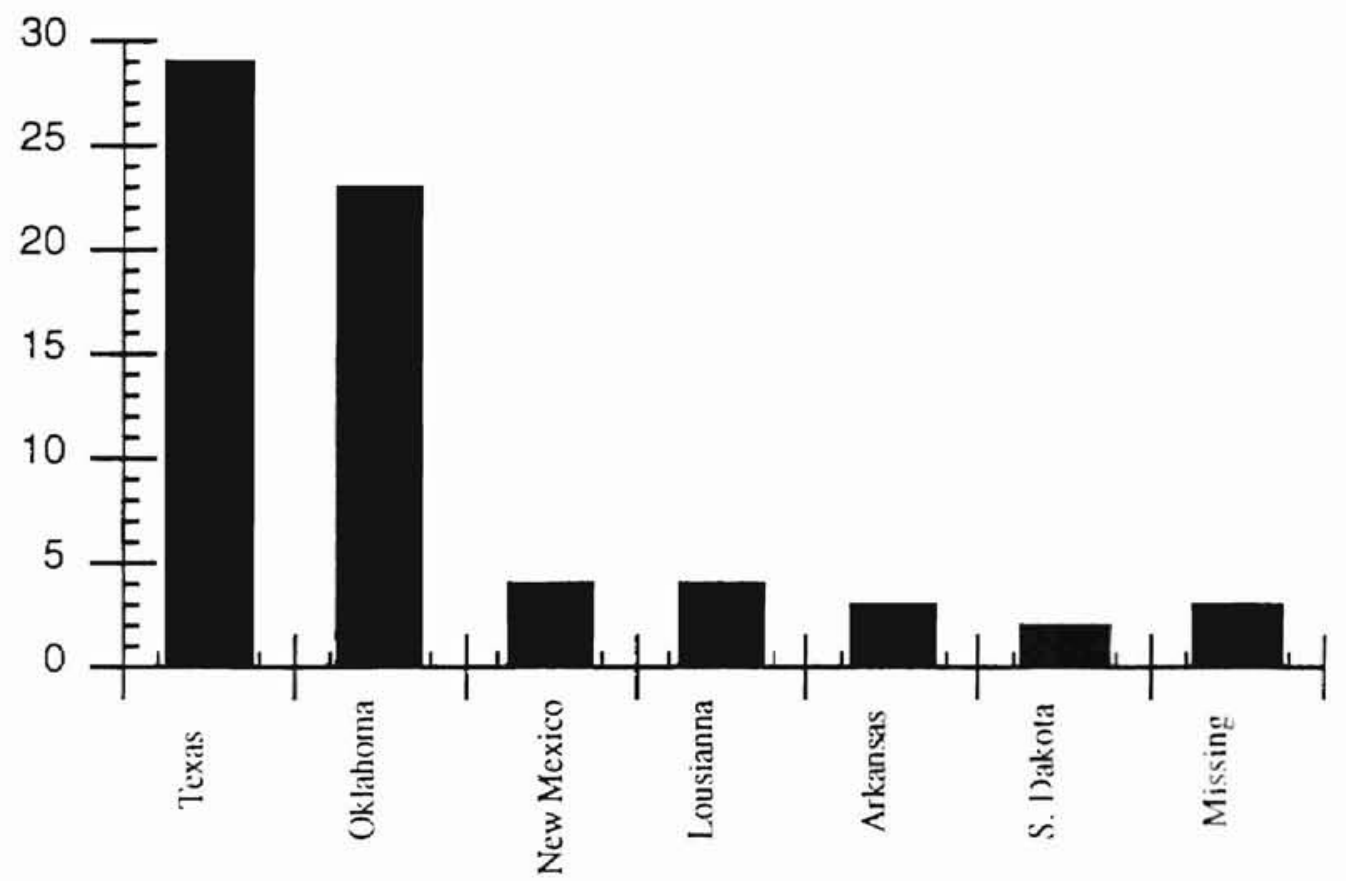

Figure 4: Worksite - Location ol Participants

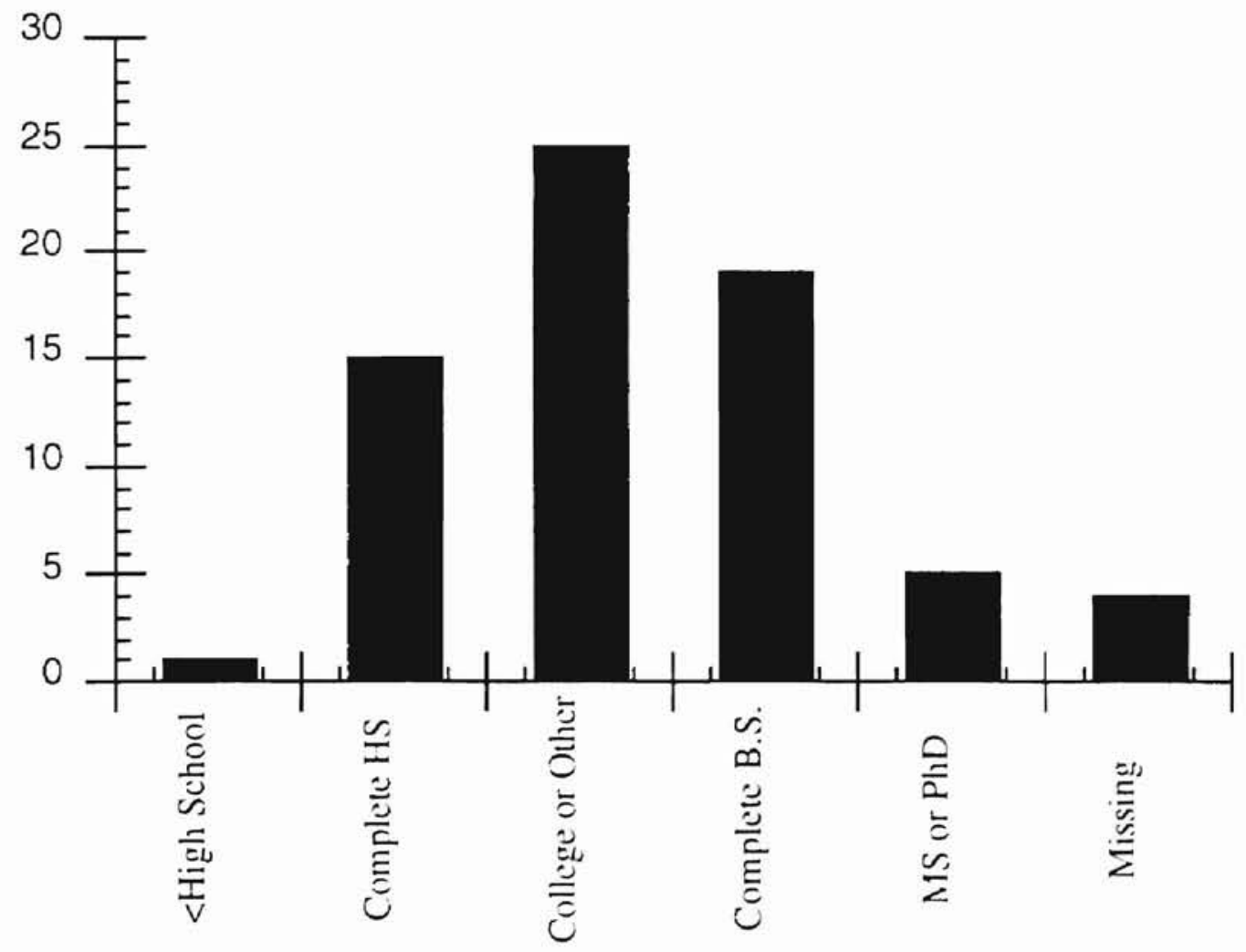

Figure 5: Education Levels of Participants 


\section{Fondservice Experience}

The participants did not completely answer all questions regarding food preparation and service experiences. Of those who provided answers, one-third indicated that they have 1-9 years of experience in Head Start. Almost half of the participants had experiences in other foodservice facilities such as commercial restaurants, churches, hospitals and nursing homes, schools and colleges and government programs. Close to one-fourth of the subjects have had 1-9 years experience in these facilities (Table II). In Manning's study (1994), institutional fondservice workers obtained work experience in hospitals and nursing homes while temporary workers had their experiences from fraternal or service clubs.

$\underline{\text { Supervisory Responsihilities }}$

Fifty-nine percent of the Head Start participants stated that their joh involved supervising fondservice workers. In contrast, $28 \%$ did not supervise foodservice workers (Table II).

\section{Attitudes of Participants Toward Standard Fond Saliety Practices}

Twenty-one statements on attitude toward food safely practices were presented in the questionnaire encompassing personal hygiene, general food handling practices. emerging pathogens and other specific safety issues. The researcher is pleased to report that this group of Head Start personnel were meeting the challenges of ford salety on warget, especially in their personal hygiene $(10(\%))$ and in general food preparatson techniques (84 - 98.5\%) as shown in Table III and Table X in Appendix G. Perhaps these participants possessed the appropriate attitudes toward fond safety hecause they had current foodservice training (Table II). 
TABLE III

ATTITUDINAL RESPONSES TOWARD FOOD SAFETY PRACTICES

Statements

\% Correct

1. Clean apron and apparel during food preparation

$1(0) .0$

2. Handwashing is important in food safety

l().0

3. Wash hands after handling raw meat or poultry

$1(x) .(1)$

4. A TB skin test is importunt for foodservice workers

1()$(1)(1)$

5. Always wear a hair restraint when preparing fond at work.

98.5

6. Do not combine leftover food with fresh food

96.0

7. Do not eat during food preparation or service except to taste appropriately.

96.0

8. Food handlers may not smoke in food preparation and service areas.

95.5

9. When in douht throw it out

93.11

10. Use of a thermometer to ensure food is safe to eat

9.3 .0

11. Sanitizing agents should he used to clean food preparation surfaces

9).(1)

12. Okay to thaw frozen fond on counter

()(1) (1)

13. Reheat leftovers to $165^{\prime \prime} \mathrm{F}$ or $>$

$84 .(1)$

14. Container depth is important when refrigerating hot food

78.11

15. Food at room temperature $>9()^{\prime \prime} \mathrm{F}$ should not he left out more than 1 hour

$76 .(1)$

16. Been trained to avoid an E. coli outhreak. 46.1$)$

17. Know what the letters HACCP represent 4.3.0

18. Cooling hot foods to room temperature belore refrigerating

19. Tell by my nose or taste if fond item would makc a person sick 4(1).()

20. Final internal temperature of ground heef is 150$)^{\prime \prime} \mathrm{F} \quad 31$ ()

21. Prepare and serve food in an institutional setting the same as at home. 20.5 See Also Appendix G, Tahle X 
Personal hygiene included wearing clean aprons and apparel during food preparation, frequent handwashing. having a TB skin test, and wearing a hair restraint when preparing food. This study was in agreement with Manning (1994) on wearing clean apparel (Manning, 1994). General food preparation techniques were composed of restraining hair, avoiding cross-contamination, not eating in food preparation areas, and not smoking during food preparation. Also, the majority of subjects responded appropriately regarding use of thermometers to determine food temperatures. sanitizing food preparation surfaces, handling leftover foods, not thawing foods at room temperature. depth of container used for refrigerating hot foods and not leaving food at room temperature over one hour.

The researcher is concerned, however, that these participants were not knowledgeable regarding E. coli, HACCP and end point temperature of cooked ground beef. With the Ecoli and salmonella outbreaks, personnel involved in food preparation need in-depth training on these subjects.

\section{Knowledge of Participants Regarding Standard Food Safety Handling Practices}

Almost all of the participants knew that raw meat, eggs of lish should he kept separate from cooked foods during preparation $(\mathrm{N}=66.97 \%)$ and that appropriatc utensils or supplies should be used in handling cooked fords ( $N=64,94 \%)$ (Tahle IV and Table IX, Appendix G). In a similar study by Manning (1994), only ahout half of her subjects knew about appropriate handling of cooked foods. Sixty-two of the 68 participants (9) $1 \%$ ) also knew that employees with communicable discases should not handle lood, while 57 (84\%) believed that to avoid contamination, a food handler should wash hands often.

Head Start participants, however, have only average knowledge with regards o temperature control and cooling/reheating of foods. Albrecht et al. (1992) reported that $75 \%$ of the respondents answered correctly regarding proper cosoling and $6(1 \% \%$ regarding 
TABLE IV

KNOWLEDGE OF FOOD SAFETY

1. It is true that raw meat, poultry eggs or fish should be kept separate from cooked foods during preparation.

2. When handling cooked foods you should use appropriate utensils or supplies such as plastic disposable gloves, waxed paper, use forks, tongs or long-handled spoons or scoops.

3. Employees with communicable diseases should not handle food as long as they are sick.

4. A food handler should wash his or her hands after every possibility of contamination.

5. Salads containing meat, poultry, eggs, or fish should the prepared with pre-cooled ingredients whenever possible.

6. It is true that hot foods should he kept above 140$)^{\prime \prime} \mathrm{F}$ and cold foods below

7. Frozen foods should he received and stored at (l"F.

8. The maximum height of pans used to cool and store food in refrigerators should he not more than 4 inches.

9. Dishes should he washed, rinsed and sanitized, and kitchen equipment (such as slicers and grinders) also should he washed, rinsed \& sanitized.

10. Cooked foods cannot he held at room temperature for more than 3 hours because the bacteria have been killed during cooking. 
adequate reheating. When asked if pre-cooled ingredients should be used in salads made with potentially hazardous foods, only $72 \%(n=49)$ of the subjects answered correctly. Regarding the holding temperatures with the danger zone being hetween 40$)^{\circ} \mathrm{F}-14()^{\prime \prime} \mathrm{F}$ $\left(4.5^{\circ} \mathrm{C}-60^{\circ} \mathrm{C}\right)$, two-thirds of participants answered correctly. The temperature of $45^{\prime \prime} \mathrm{F}$ $\left(7^{\circ} \mathrm{C}\right)$ may have been a complicating factor since different standards have been used over the years, and some temperature standards vary by jurisdiction. The present temperature standard for cold food according to the 1995 Food Code is below $41^{\prime \prime} \mathrm{F}$ ( $5^{\circ} \mathrm{C}$ ). Regulatory bodies should further clarify cold temperature standards throughout the foodservice industry. Waites \& Arbuthnott (1990) asserted that:

"The aim of advisory hodies and governments must be to clarify lood safety issues and to establish eflective guidelines for control of production, processing, distribution, and sale of food. Additionally, clear guidance on hygienic handling and cooking of tood in catering establishments and in the home is needed" (p.722).

The correct receiving temperature of frozen foods, ()$^{\prime \prime} \mathrm{F}\left(-18^{\prime \prime} \mathrm{C}\right)$, was correctly identified by $60 \%$ of the subjects in this study. Half of the suhjects correctly answered that the height of pans should not exceed 4 inches, which is proportionally better than Mamning's results (1994). Only $21 \%$ of institutional foodservice workers and $13 \%$ of temporary foodscrvice workers answered this question correctly in Manning's study (1994).

Serious concerns regarding answers to the following two yuestions were brought out in this study. A majority of the participants $(n=60), 88 \%)$, incorrectly answered that kitchen equipment such as slicers and grinders only need to be wiped ofl wilh a damp sponge or cloth while dishes should he washed, rinsed and sanitized. Only $6 \%$ of the surveyed participants knew the correct answer regarding handling of cooked loods. Many of the subjects $81 \%(n=55)$ did not know that cooked fond cannot be held at room temperature for more than 3 hours. In contrast, Alhrerecht et al. (1992) stated that $9(1 \%$ of the respondents in their study answered correctly on questions about appropriate: temperatures for food storage, and reheating or holding foods. 


\section{Statistical Analyses}

\section{Attitudes Toward Fond Safety Practices}

$\mathrm{H}_{\mathrm{O}}$ 1: There will be no significant associations between Head Start participants attitudes toward food safety practices and the selected demographic variables: gender, age. education level, training, years of experience, types of operations, and supervisory responsibilities.

Analysis of Variance (ANOVA) procedure indicated an association between attitudinal practice ratings and education level at $\mathrm{p}=.00(36$ (Table V). Subjects with bachelor's or graduate degrees scored signiticantly better, as expected, on attitudes than those with only some college education or high school diplomas as determined hy Duncan's Multiple Range Test (Table VI).

\section{TABLE V}

ANALYSIS OF VARIANCE (ANOVA) FOR ATTITUDINAL PRACTICE RATINGS AND EDUCATIONAL LEVEL

\begin{tabular}{lrccc}
\hline Source & $\mathrm{di}$ & Mean Square & $\mathrm{F}$ & $\mathrm{P}$ \\
\hline Model & 2 & 169.12 & 6.31 & .010 .36 \\
Error & 50 & 26.80 & & \\
Total & 52 & & & \\
\hline
\end{tabular}

TABLE V]

DUNCAN'S MULTIPLE RANGE TEST F(OR ATTITUDINAL PRACTICE RATINGS AND EDUCATIONAL LEVEL

\begin{tabular}{llcc}
\hline Education & N & Mein & Group* \\
\hline High School & 11 & 38.82 & $\mathrm{~A}$ \\
Some College or Other School & 21 & 37.81 & $\mathrm{~A}$ \\
College/Graduate & 21 & 33.05 & $\mathrm{~B}$ \\
\hline
\end{tabular}

${ }^{*}$ Means with the same letter are not signilicant at the $\rho \leq 0.015$ level. 
An association was found between attitudes toward food safety practices and on the job training by a supervisor as determined by t-test procedure at $\mathrm{p} \leq 0 .(15$ (Table VII). This seemed reasonable since most employees respect their supervisors and information received from them (supervisors) was put into practice. Attitudes toward food safety practices were also significantly associated with training provided hy the local health department as revealed with a t-test procedure at $\mathrm{p}=0 .(16$. Many jurisdictions requirc foodservice workers to have a card which is issued on an annual hasis for attending and passing a safe food handling class. Since employees are frequently refreshed on this information, it stands to reason that it has a positive effect on their attitude toward safe food handling. This course and a food handling card may be two of the more valuable requirements in foodservice.

Subjects displayed signilicantly $(p=0.06)$ totter attitudinal practices towards food safety if they had prepared food in other places as shown by a t-lest procedure (Table VII). Additionally, food safety attitudes were significantly $(p=.10296)$ associated with the number of years of experience of participants (Tahle VII). Those who had less than 10 years experience in preparing food at other places scored significantly hetter on the attitude score than those with 10 or more years of food preparation in other places. Perhaps those on the joh a long time were complacent toward their joh and needed periodic retraining.

TABLE VIJ

T-TEST DETERMINATION ON ATTITUDINAL PRACTICES AND TRAINING AND EXPERIENCE

\begin{tabular}{|c|c|c|c|c|c|c|c|}
\hline \multirow[t]{2}{*}{ Group } & \multicolumn{2}{|l|}{ Yes } & \multicolumn{3}{|c|}{$\underline{\mathrm{N}_{1}}$} & \multirow[b]{2}{*}{ SD } & \multirow[b]{2}{*}{ P-Vulue } \\
\hline & Mean & $\mathrm{N}$ & SD & Mean & $\mathrm{N}$ & & \\
\hline OJT By Supervisor & 36.78 & 32 & 6.64 & 34.82 & 17 & 3.6 .3 &.$(1) 1313$ \\
\hline Health Dept. Course & 36.44 & 27 & 6.77 & 35.68 & 22 & 4.48 & (1)571 \\
\hline Experience Other Places & 35.56 & 25 & 4.27 & 37.74 & 19) & 6.45 &.$(1)(x) 1$ \\
\hline Years of Prep/Other Facilities & 35.77 & 47 & 6.11 & 36.44 & 9 & 2.88 & .1296 \\
\hline
\end{tabular}


If you look at the association between food safety attitudes and the education level. training, and level of experience of the participants, the researcher rejected $\mathrm{H}_{0} \mathrm{l}$ in part. There were no significant associations between food safety attitudes and gender, age, years of experience, types of operations and supervisory responsibilities; therefore the researcher failed to reject $\mathrm{H}_{0}$ l based on these variables.

The researcher expected to obtain significantly better ratings of attitudes from participants who supervised since they teach the workers and should also demonstrate good attitudes. The lack of association between gender, age, and years of experience, toward food safety was not expected. Results might have heen significant if the sample had heen larger. Continued research is needed to determine exactly what types of training and experience continue to give positive results relative to safe food handling attitudes.

\section{Fnond Safety Knowledge}

$\mathrm{H}_{0}$ 2: There will be no significant associations between fond salety knowledge of workshop participants and the selected demographic variahles as listed in $\mathrm{H}_{0} \mathrm{l}$.

A t-test procedure was used to determine the association hetween the subjects' scores on food safety knowledge and their demographic characteristics. T-test analyses indicated that there was a significant association $(p=0 .(1727)$ hetween suhjects' gender and knowledge of food safety (Tahle VIII). Males scored higher on knowledge of sali loud handling than females. Males may have been directors, while the liemales johs ranged from cooks to supervisors and professionals. The females who attended the nutrition workshop may have assumed they knew the correct answers and did not put out much effort. Additionally, the males in this group may have listened more carefully and worked harder to determine the correct answers. 
TABLE VIII

t-TEST DETERMINATION ON FOOD SAFETY KNOWLEDGE AND GENDER

\begin{tabular}{lcrrrr}
\hline Group & Mean & $\mathrm{N}$ & $\mathrm{SD}$ & $\mathrm{df}$ & P-Value \\
\hline Males & 8.67 & 9 & $1 .(1)$ & 8 & .0727 \\
Females & 7.26 & 58 & 1.83 & 57 & \\
\hline
\end{tabular}

Based on this one association $\mathrm{H}_{0} 2$ is rejected in part. When the remainder of the demographic characteristics were considered, however, the researcher failed to reject $\mathrm{H}_{\mathrm{o}} 2$. Although there was no significant association between knowledge and education level. those with higher levels of education scored hetter than those with high school degrees. The insignificant results may have been due to a small sample and only having 10 questions in the food safety knowledge area.

\section{Knowledge and Attitudes}

$\mathrm{H}_{0} 3$ : There will be no significant associations hetween ford safety knowledge and food safety attitudinal practices of workshop participants.

The association between knowledge scores and attitude rating is illustrated in a scatterplot (Figure 6). Quadrant four (4) represents the number of subjects who displayed good attitudinal practices along with high knowledge scores. There were 19 suhjects in this quadrant. Seventy-tive percent $(n=41)$ (quadrant $3 \& 4$ ), of the participants had high knowledge scores on food safety while only $34 \%(\mathrm{n}=2.3)$ of them showed high attitudinal ratings. The researcher postulated that the higher the knowledge score the hetter the attitudes toward safe food handling. Even though this is not a strong correlation, the higher score on knowledge had statistically significant association with the attitudinal practices towards food safety. Pearson's correlation coeflicient of $r=-1) .45$ (Tahle IX) indicated a weak association, therefore, the researcher rejected $\mathrm{H}_{0} 3$. 


\begin{tabular}{|c|c|c|c|c|c|c|c|c|}
\hline \multirow[b]{3}{*}{ LOW } & \multicolumn{3}{|c|}{ LOW } & & & & \multicolumn{2}{|r|}{ HIGH } \\
\hline & & 4 & 5 & 6 & 7 & 8 & 9 & 10 \\
\hline & 47 & & & Q1 & 1 & & & $\mathrm{Q2}^{2}$ \\
\hline & 46 & & & & 1 & & 1 & \\
\hline & 45 & & & & & & & \\
\hline 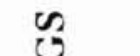 & 44 & 1 & & & & & & \\
\hline $\mathbf{z}$ & 43 & & 1 & & & 3 & & \\
\hline$E$ & 42 & 1 & 2 & & & & 1 & \\
\hline$\lesssim$ & 41 & & & & 1 & & & \\
\hline $\bar{s}$ & 40) & 1 & & 1 & 1 & & & \\
\hline$\underline{U}$ & 39 & & & & 1 & & & \\
\hline 5 & 38 & & & 1 & 3 & 2 & 1 & \\
\hline$<$ & 37 & & 2 & & 1 & & 2 & \\
\hline$\simeq$ & 36 & & & & & & 3 & \\
\hline & 35 & & & Q3 & & & & $Q_{4}$ \\
\hline$\frac{1}{2}$ & 34 & & 1 & & 1 & & 1 & 1 \\
\hline$\underline{z}$ & 33 & & & & & 1 & 1 & 1 \\
\hline 5 & 32 & & & 1 & & & 2 & \\
\hline$\underline{E}$ & 31 & & & 1 & & & 1 & 1 \\
\hline$E$ & $30)$ & & 1 & & & & 1 & 1 \\
\hline 4 & 29) & & & & & & & \\
\hline & 28 & & & & & & 1 & 1 \\
\hline & 27 & & & & & & & \\
\hline HIGH & 26 & & & & & 2 & I & 2 \\
\hline
\end{tabular}

KNOWLEDGE

Figure 6: Comparison of Knowledge Score and Attitudinal Practice Rattings

\begin{tabular}{lrc}
\hline Q=Quadrant & N & $\%$ \\
\hline Q1 = Low Attitudinal Practices \& Low Knowledge & 11 & 15 \\
Q2 = Low Attitudinal Practices \& High Knowledge & 22 & 32 \\
Q3 = High Attitudinal Practices \& Low Knowledge & 4 & 6 \\
Q4 = High Attitudinal Practices \& High Knowledge & 19 & 30 \\
Missing Data & 13 & 19 \\
Q3 \& Q4 = High Attitudinal Practices Ratings & & \\
Q2 \& Q4 = High Knowledge & 23 & 34 \\
Missing Data & 41 & 60 \\
\hline
\end{tabular}


TABLE IX

PEARSON'S CORRELATION COEFFICIENT OF FOOD SAFETY KNOWLEDGE AND ATTITUDINAL PRACTICES

\begin{tabular}{|c|c|c|c|c|}
\hline Variable & $\mathrm{N}$ & Mean & Std Dev & Sum \\
\hline Knowledge & 67 & 7.45 & 1.80 & $499 .(x)(1)$ \\
\hline Attitude & 56 & 35.88 & 5.70 & $2(x) 9$ \\
\hline$\overline{\text { RANGE }}$ & \multicolumn{2}{|c|}{$\begin{array}{l}\text { MINIMUM } \\
\text { Score/Rating }\end{array}$} & \multicolumn{2}{|c|}{$\begin{array}{l}\text { MAXIMUM } \\
\text { Score/Rating }\end{array}$} \\
\hline Knowledge & & & \multicolumn{2}{|c|}{10.00} \\
\hline Attitude & & & \multicolumn{2}{|c|}{$47.00)$} \\
\hline KNOWLEDGE & & & \multicolumn{2}{|c|}{$-(0.4541$} \\
\hline ATTTTUDE & & & \multicolumn{2}{|c|}{1.00000} \\
\hline
\end{tabular}

The researcher expected increased knowledge to be associated with hetler attitudinal practices. When individuals have more knowledge, they usually have improved work habits. The results of this study emphasized the need to provide further training and follow-up to ensure that what is learned is also applied in the workplace. If a pre-test and post-test had been done, results related to knowledge and training might have heen signilicantly better. More research is needed to determine the variables that do impact forod safety attitudinal practices and knowledge. 


\title{
CHAPTER V
}

\section{SUMMARY, RECOMMENDATIONS AND IMPLICATIONS}

\author{
Summary
}

The challenge of food safety for Head Start personnel was explored in this study. Three hypotheses were postulated to determine if selected variables were related to ford safety attitudes and knowledge. A questionnaire was developed hy the researcher to ohtuin data from the participants at a Head Start Nutrition workshop in San Antonio Texas.

The questionnaire was developed in three sections: (1) the first section contained statements about fond safety attitudes, (2) the second section included I () lood safely knowledge questions, and (3) the third section was comprised of demographic information. This questionnaire was approved hy the Instititutional Review Board at Oklahoma State University. The results of the data collected firom the questionnaires completed by the workshop participants are presented in Chapter IV. The sample population were volunteers from six states who attended a workshop on Head Start Nutrition in San Antonio. Texas. Data ohtained from 68 questionnaires were analyad using frequencies, percentages, t-lests, ANOVA, Duncan's Multiple Range Tests and Pearson's Correlation Coefficient.

The majority of the respondents, $(n=47)$ were 35 years of age and older. There were almost six times as many females as males in this study. Among the participants, the majority lived in Texas and Oklahoma and had some college or other education. Courses offered by the local health departments were significantly associated with helter attitudes toward fond salety practices. 
Participants displayed appropriate attitudes regarding wearing clean aprons and clothes, not smoking in food preparation areas, frequent washing of hands and wearing a hair restraint when preparing food at work. Participants were very secure in their attitudes regarding washing hands after handling raw meat or poultry, requining foodservice employees to have tuberculosis skin test and not eating during food preparation or service except for appropriate tasing of foods before service.

Subjects were unsure if they could identify by smell or taste when a food item would make a person sick, and whether hot food should he cooled to room temperature before being refrigerated. A majority of the subjects inconectly agreed that food can he prepared the same at work as prepared at home. In the technical support paper tor the American Dietetic Association's position on nutrition standards for child care programs. Briley \& Roberts-Gray, (1994) stated: Cooking and serving food for a large group of children is different from preparing foods for one's family. It is important that good institutional food management practices be implemented to protect the health and saliety of children (p. 326). Almost 7()\% were incorrect, not sure, or did not respond to the statement regarding the end temperature of cooked ground heef. Ahout hall of the suhjects were unable to identify what the letters HACCP represented and a majority had not had training to avoid an E. coli outhreak. Subjects incorrectly answered knowledge questions related to holding cooked food for more than three hours at room temperatures, sanitizing kitchen equipment, and the maximum height of pans used to store and cool food in refrigerators.

The relationship between higher scores on knowledge and heller ratings on attitudinal practices toward food safety was statistically significant. This would he expected since people should be able to put their knowledge into appropriate practice. Applying information gained from scientific research to everyday practice is a positive strength any foodservice professional should be proud to possess. 


\section{Recommendations}

The study could have been done statewide and/or nationwide to ohtain a larger sample to analyze. The researcher did not get the ethnic breakdown and the subjects" joh titles in the demographics and these would be very useful it the study was repeated. Changing the word attitudes to practices could be desirable in future studies: In future studies, a pre-test, post-test design would he very heneficial. Additionally, comparing the test results with actual observations of correct and/or incorrect practices would be very interesting and could provide a different perspective. Conducting a study to investigate the attitudes and knowledge of foodservice workers in Head Start. Child Care and/or School Food and Nutrition Services workers could have heen helptul, especially since there is a discernible difference hetween the amounts and levels of training the groups are required to attain.

\section{Implications}

The 1995 Food Code will become an increasingly valuable fool as mone fordscrvice operations implement a Hazard Analysis and Critical Control Points sell-inspection system. HACCP is a monitoring program that encompasses all aspects of the loodservice operation from purchasing to consumption of the finished product. It cnsures that sale food handling practices are carried out and hazards are identified, eliminated, or signilicantly reduced. HACCP is the tool that regulatory hodies are depending on to keep foodhome illiness outbreaks from increasing significantly. "Since new hazards are emerging from hoth familiar pathogens such as salmonella and previously unrecognized microhial threats. improved surveillance for foodhorne infections is essential" (Hennessey et al., 1996.. 1324)

This study will be useful in providing a tool to assess fondservice workers current level of knowledge and practical food safety attitudes. Results of this research indicated the importance of training foodservice workers in order to prevent foodhome illness 
outbreaks. Training has to be continuous. Foodservice handlers must be motivated to practice appropriate procedures and must have the self-discipline to follow-through on what they know regarding safe food handling practices. Everyone who is involved in foodservice needs to he updated on current food safety concerns and procedures. Updated training and re-certification every six months cannot be overemphasized hecause the turnover rate is usually high in foodservice operations. Waites \& Arhuthnot stated "It is the responsibility of managers that all staff are adequately trained in hasic food hygiene" (1990, p. 724). Management must be ever vigilant to ensure that correct food safiety practices are being adhered to in their foodservice operations.

Head Start is an excellent program serving children at risk, and to maintain its status, high quality comprehensive services must be a priority. Head Start needs to ensure that all programs can deliver on its vision, by striving for excellence in serving hoth children and families. Excellent service delivery will depend on improved and continuous staff training and career development for Head Start workers. Future follow-up studies should be conducted to determine if Head Start personnel continue to have acceptahle knowledge and attitudes toward food safety in carrying out their responsihilities of serving a vulnerable population group--children. 


\section{REFERENCES}

Administration on Children, Youth and Families, Fact Sheet Head Start, Washington. D.C.: The US Government Printing Office, 1994.

Administration on Children, Youth and Families, Project Head Start Statistical Fact Sheet, Washington, D.C.: The US Government Printing Office, 1995.

Albrecht JA, Sumner SS, Henneman, A. Food Safety in Child Care Facilities. Dairy. Food and Environmental Sanitation. 1992: 92 (12):74()-743.

American Dietetic Association, Position of The American Dietetic Association: Nutrition

Standards for Child Care Programs. Journal of the American Dientefic Association. 1994; 94 (3):323.

Armstong T. SERVSAFE Serving Safe food Certificarion Coursebook. Chicago, IL: National Restaurant Assocation The Educational Foundation, 1995

Best JW. Research in Education. Englewood Cliffs, NJ: Prentice-Hall, 1981.

Bauman HE. The HACCP Concept and Microhiological Hazard Categories. Fond Technology. 1974: September 1974: 3()-34.

Bobeng BJ \& David BD. HACCP Models for Quality Control of Entree Production in Fondservice Systems. Journal of Food Protection, 1977: 77 (4(1):64.3-6.38.

Bobeng BJ \& David BD. HACCP Models for Quality Control of Entree Production in Hospital Fondservice Systems. Journal of The American Dietetic A.siseriation. 1978; 78 (73):524-5.35.

Briley ME \& Roberts Gray C. Identification of Factors that Influence the Menu at Child Care Centers: A grounded theory approach. Joumnal of the American Dietetic Association. 1994; 94 (3):276-281.

Briley ME \& Roberts Gray C. Nutrition Standards in Child Care Programs: Technical support paper. Journal of the American Dieteric Association. 1994; 94 (3):324328 .

Brinkman E, VanBeurden R, Mackintosh R, \& Beumer R. Evaluation of the New Dipstick Test for the Rapid Detection of Salmonella in Food. Journal of Food Protection.. 1995; 95 (58):1(123-10127.

Bryan FL. Microbiological Fond Hazards Today-Based on Epidemiological Information. Food Technology. 1974; September, 1974:52-64. 
Bryan FL. Risks of Practices, Procedures and Processes that Lead to Outbreaks of

Fondborne Diseases. Journal of Food Protection. 1988; 88 (51):66.3-673.

Bryan FL. Hazard Analysis Critical Control Point (HACCP) Systems for Retail Food and Restaurant Operations. Journal of Food Protection. 1990; 9() (53):978-983.

Byers BA, Shanklin CW, \& Hoover LC. Food Service Manual for Health Cure' Institutions. Chicago, IL: American Hospital Publishing, Inc., 1994.

Centers for Disease Control. Fondhome Disease Outbreaks, 5-year Summary, 198.3-1987. CDC Surveillance Summaries. Atlanta, GA.: 1990. MMWR. 199(): 39(SS-1):1557.

Centers for Epidemiology \& Animal Health. (March, 1994). Escherichia coli O157:H7: Issues and Ramifications. Ft. Collins, CO: USDA:APHIS:VS.

Claudio VS \& Lagua RT. Nutrition and Diet Therapy Dictionary. New York. NY: Van Nostrand Reinhold, 1991.

Cliver DO. Research Needs in Fond Safety. Food Technology. 1993: March .1993: 10S$13 \mathrm{~S}$.

Cooke EM. Epidemiology of Foodhorne Illness: UK. The Lancet. 199(1) (3.36)79(1)-795.

Food Code. Washington, DC: United States Department of Health and Human Services: 1995

Giese J. Rapid Microbiological Testing Kits and Instruments. Food Technology. 1995: July:64-71

Hennessey TW, Hedherg CW, Slutsker L, White KE, Beseer-Wiek JM, Moen ME, Feldman J, Coleman WW, Edmonson LM, Macdonald KL. Osterholm MT,\& The Investigation Team. A National Outhreak of Salmonelles Enteritirdis Infections from Ice Cream. The New England Journal of Medicinc. 196)(3.34 (20):1281-1286.

Holt PS, Gast RK, \& Greene CR. Rapid Detection of Salmonella enteritidis in Pooled Liquid Egg Samples Using a Magnetic Bead-ELISA System. Journal of Food Protection. 1995: (58):967-970.

Kendrik AS. Training To Ensure Healthy Chidl Day-Care Programs. Pediatrics. 1994: 84 (6): $11(18-111(1)$

Manning CK \& Snider OS. Temporary Public Eating Places: Food Safety Knowledge, Attitudes and Practices. Jounnal of Envirommental Health. 199.3; 56:24-28.

Manning CK. Food Safety Knowledge and Attitudes of Workers from Institutional and Temporary Fondservice Operation. Joumal of the American Dietetic Association. 1994; $94(8): 895-897$.

Marks S \& Roberts T. E.coli O157:H7 Ranks as the Fourth Most Costly Foodhorne Disease. FoodReview. 1993; 93 (16):51-59.

Martin R. Push for Safety: A Quiet Crusade. Nation's Restaurant News. 1993: 27 (25):1 $\& 75$. 
Monsen ER. Research Successful Approaches. Chicago IL: The American Dietetic Association, 1992.

National Head Start Association, Silver Ribbon Panel. Head Start: The Nation 's Pride, A Nation's Challenge, Alexandria, VA: The Association, 199().

Novello AC, MDM. The Role of the Public Health System in Child Day-Care Health. Pediatrics Supplement: 1994; 94 (8):1114-1116.

Ollinger-Snyder, P \& Matthews E. Fond Safety: Review and Implications for Dietitians and Dietetic Technicians. Journal of the American Dietetic Association. 1996: 96 (2):163-171.

PC-File III, Version 4.() Bellevue, WA. Buttonware Inc. 1985.

Peterson AC \& Gunnerson RE. Microbiological Critical Control Points in Frozen Foods. Food Technology. 1974: September, 1974:37-44.

Pond-Smith D, Richarz SH, \& Gonzalez NL. A Survey of Foodservice Operations in Child Care Centers in Washington State. Journal of the Americrm Dietetic Association. 1992; 92 (4):48.3-484.

Statistical Analysis System, Version 5. Cary, NC: SAS Institute Inc., 1985.

Spears MC. Foodservice Organizations A Managerial and Systems Approach, 3rd ed Englewood NJ: Prentice-Hall, Inc., 1995.

Schorr LB. Within Our Reach: Breaking the Cycle of Disadvantage' New York: Doubleday, 1988.

Waites WM \& Arhuthnot JP. Foodhorne Illness: An ()verview. The Lancet. I9)(): 9)() (3.36):722-725.

Zigler E \& Muenchow S. Head Start: The Inside Story of America's Most Successful Educational Experiment. New York: Basic Books. 1992.

Zigler E \& Valentine J. Project Head Start: A Legacy of the W'ar on Porerry. New York: The Free Press, 1979. 
APPENDIXES 
APPENDIX A

COVER LETTER AND QUESTIONAIRE 
March 1, 1995

Greetings Healthy Start Workshop Paricipant!

You have been chosen to participate in a very important study entitled "Food Safety Knowledge of Child Nutrition Food Service Personnel." Since young children are extremely vulnerable to outbreaks of foodbome illness it is very important that the workers who prepare their food have adequate training and correct information regarding the preparation and handling of food. When children receive meals from a child care program the worker involved in the preparation of food is responsibie for maintaining the child's well-being by preventing foodborne illnesses. This survey will be used to assess food safety knowledge

Please take 10 minutes of your time to complete the questionnaire provided Your cooperation and participation are very much appreciated. You do not need to sign your name as all data will be treated confidentially and no individual information or place of employment will be identified. A summary of results will be made available to participants who are registered for the workshop.

Although, participation in this study is voluntary, in appreciation for taking part, there will be a special treat for you at the registration desk. To receive your treat put the completed questionnaire in the box provided at the registration desk Again, we thank you for your time and participation in this project.

Sincerely,

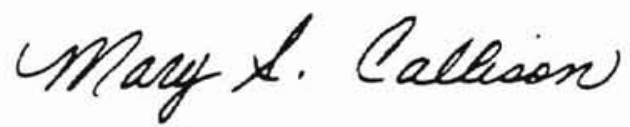

Mary S Callison

Graduate Student

dea 2 tobo

Lea L. Ebro, Ph.D., R.D

Major Advisor 
Do not sign your name.

Foed Safety Qeentionanire

I. HOW DO YOU FEEL ABOUT THESE STATEMENTS?

Please circle the number which best describes your opunion on a scale of 1 (Strongly Agree) to 5 (Str ongly Disagree):

\begin{tabular}{|c|c|c|c|c|c|}
\hline & $\begin{array}{c}\text { Strongly } \\
\text { Agree }\end{array}$ & Agree & $\begin{array}{l}\text { Not } \\
\text { Sure }\end{array}$ & Disagree & $\begin{array}{l}\text { TStrongly } \\
\text { I Disagree }\end{array}$ \\
\hline $\begin{array}{l}1 \text { When I am at work prepanng food. I } \\
\text { always wear a clean apron and } \\
\text { ciean clothes. }\end{array}$ & 1 & 2 & 3 & 4 & 8 \\
\hline $\begin{array}{l}2 \text { Food handlers may smoke in food } \\
\text { preparation and service areas. }\end{array}$ & 1 & 2 & 3 & 4 & 5 \\
\hline $\begin{array}{l}3 \text { i believe that frequent and thorough } \\
\text { hanowashing is very important in } \\
\text { keeping food safe to eat. }\end{array}$ & 1 & 2 & 3 & 4 & 5 \\
\hline $\begin{array}{l}4 \text { I always wear a hair restraint (haimet } \\
\text { or cap) when preparing food at work. }\end{array}$ & 1 & 2 & 3 & 4 & 5 \\
\hline $\begin{array}{l}5 \text { I believe that a sanitizing agent should } \\
\text { be used to clean the surfaces on which } \\
\text { i prepare both raw and cooked tood. }\end{array}$ & 1 & 2 & 3 & 4 & 5 \\
\hline $\begin{array}{l}6 \text { It is okay to thaw frozen food on the } \\
\text { kitchen counter prior to preparation. }\end{array}$ & 1 & 2 & 3 & 4 & 5 \\
\hline $\begin{array}{l}7 \text { I can tell by my nose or taste when a } \\
\text { food item would make a person sick }\end{array}$ & 1 & 2 & 3 & 4 & 5 \\
\hline $\begin{array}{l}8 \text { Hot foods should be cooled to room } \\
\text { remperature before being placed in the } \\
\text { refrigerator. }\end{array}$ & 1 & 2 & 3 & 4 & 5 \\
\hline $\begin{array}{l}9 \\
\text { I believe that a thermometer is a } \\
\text { necessary tool in making sure that food } \\
\text { is sate to eat. }\end{array}$ & 1 & 2 & 3 & 4 & 5 \\
\hline $\begin{array}{l}10 \text { In order to prevent foodbome illness, } \\
\text { previously cooked foods such as meat } \\
\text { or pouttry should be thoroughly reheated } \\
\text { to } 165^{\circ} \mathrm{F} \text { or higher. } \\
\end{array}$ & 1 & 2 & 3 & 4 & 5 \\
\hline $\begin{array}{l}11 \text { When I am in doubt about the safely of } \\
\text { a previously cooked food. I throw it out } \\
\text { rather than serve it. }\end{array}$ & 1 & 2 & 3 & 4 & 5 \\
\hline $\begin{array}{l}12 \text { After handling raw meat or poultry. I } \\
\text { latways wash my hands with soap and } \\
\text { water. }\end{array}$ & 1 & 2 & 3 & 4 & 5 \\
\hline $\begin{array}{l}13 \text { The depth of the container is important } \\
\text { when placing hot food in the refrigerator } \\
\text { ho be cooled. }\end{array}$ & 1 & 2 & 3 & 4 & 5 \\
\hline $\begin{array}{l}14 \text { When the room temperature is } 90^{\circ} \mathrm{F} \\
\text { or above, cooked food should not be left } \\
\text { out ionger than } 1 \text { hour before reheating } \\
\text { or refrigerating or freezing. }\end{array}$ & 1 & 2 & 3 & 4 & 5 \\
\hline $\begin{array}{l}151 \text { prepare and serve the food here at work } \\
\text { in the same manner I prepare and serve } \\
\text { food at my home. }\end{array}$ & 1 & 2 & 3 & 4 & 5 \\
\hline $\begin{array}{l}16 \text { ithink it is important for foodservice } \\
\text { workers to have a tuberculosis skin } \\
\text { lest. }\end{array}$ & 1 & 2 & 3 & 4 & 5 \\
\hline $\begin{array}{l}17 \\
\text { ido not combine leflover food with } \\
\text { fresh food. }\end{array}$ & 1 & 2 & 3 & 4 & 5 \\
\hline \begin{tabular}{|l|l|}
18 & know what the letters HACCP \\
represent.
\end{tabular} & 1 & 2 & 3 & 4 & 5 \\
\hline $\begin{array}{l}19 \text { Ground beef should be cooked to a } \\
\text { gemperature of } 150^{\circ} \mathrm{F}\end{array}$ & 1 & 2 & 3 & 4 & 5 \\
\hline $\begin{array}{l}20 \text { have had training about avoiding an } \\
\text { E coli outbreak }\end{array}$ & 1 & 2 & 3 & 4 & 5 \\
\hline \begin{tabular}{|c|c|}
21 & ido not eat food during preparation of \\
service except to taste appropriately
\end{tabular} & 1 & 2 & 3 & 4 & 5 \\
\hline
\end{tabular}


II. CIRCLE ONE ANSWER FOR EACH OF THESE QUESTIONS:

16. Hot foods should be kept above $140^{\circ} \mathrm{F}$ and cold foods below $45^{\circ} \mathrm{F}$

$$
\text { TRUE or FALSE or I'MNOT SURE }
$$

17. You should keep raw meal, poultry, oggs or fish separate from cooked toods dunng preparation.

TRUE or FALSE or IMMNT SURE

18. You should prepare salads containing meat, poultry. oggs or fish with pre-cooled ingrediemts whenever possible

TRUE or FALSE or I'M NOT SURE

19. Cooked foods can be held at room temperature for more than 3 hours because ine bacteria have been killed during cooking.

TRUE or FALSE or I'M NOT SURE

20. Dishes should be washed, rinsed and sanitized, but kitchen equipment (such as slicers 'and grinders) only need to be wiped off with a damp sponge or cloth.

TRUE or FALSE or I'MNOT SURE

21. The maximum height of pans used to cool and store food in refrigerators should be nol more than:
a. $\quad 10$ inches
b. 8 inches
c. 6 inches
d. 4 inches
e. Im not sure

22. Frozen foods should be recerved and stored at:
a. $32^{\circ} \mathrm{F}$
b. $20^{\circ} \mathrm{F}$
c. $0^{\circ} \mathrm{F}$
d. I'm nol sure

23. Employees with communicable diseases:

a. may handie food if they wear gloves

b. should not handle food as long as they are sick

c. have the nght to make their own decision on the matter

d. I'm not sure

24. How often should a food handler wash his or her hands?

a. once each hour

b. before beginning work and after each rest break

c. after every possibility of contamınation

d. I'm not sure

25. When handling cooked foods, you should:
a. use plastic disposable gloves
b. use waxed paper
c. use forks, tongs or long-handled spoons or scoops
d. do any of the above
e. I'm not sure

III. ABOUT YOURSELF: Please check or fill in the appropriste response.

26. Your gender $\quad$ Male — Female
27 Your age: __ younger than $25{ }^{25-34}{ }^{35-44}{ }^{45-54} 55$ \& over

28. In what state is your worksite located? 
29 What level of school have you completed?

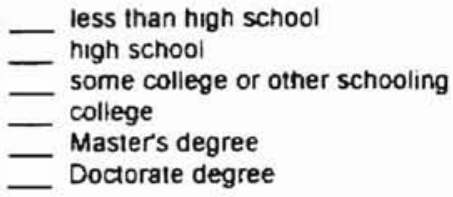

30. What kind of training or education have you had in preparing and sening food safely? (check all that apply)
a. none
b. - on-the-job by a co-worker
c. on-the-job by a supervisor
d. formal class on-the-job
e college course
$f$ - correspondence course
g. local health department course
h _ Certified Dietary Manager Course - level 1
i. - Certified Dietary Manager Course - level 2
j Certified Dietary Manager Course - level 3
k. _ other (please specity):

30. How many years have you prepared and served food at this facility? (number of years)

31. Have you ever prepared and served food in places other than this facility?<smiles></smiles>

32. If you have prepared and served food in places other than this tacility. for about how many years?

For what kind of food service operatıon? (check all that apply)

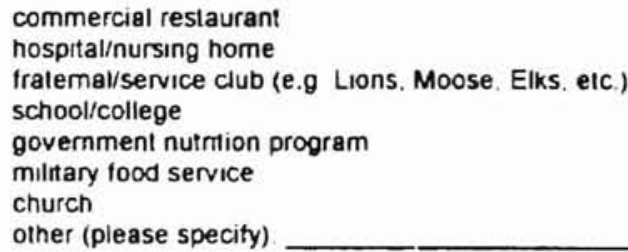

33. Does your job involve supervising foodservice workers?

$$
\longrightarrow \text { No }
$$

THANK YOUI 
APPENDIX B

INSTITUTIONAL REVIEW BOARD APPROVAL FORM 


\section{OKLAHOMA STATE UNIVERSITY \\ INSTITUTIONAL REVIEW BOARD \\ HUMAN SUBJECTS REVIEW}

Date: 07-03-95

IRB\#：HE-96-001

Proposal Title: FOOD SAFETY KNOWLEDGE AND ATTTTUDES OF HEAD START PERSONNEL

Principal Investigator(s): Lea Ebro, Mary S. Callison

Reviewed and Processed as: Exempt

Approval Status Recommended by Reviewer(s): Approved

ALL APPROVALS MAY BE SUBJECT TO REVIEW BY FULL INSTITTIONAL REVIEW' BOARD AT NEXT MEETING.

APPROVAL STATUS PERIOD VALID FOR ONE CALENDAR YEAR AFTER WHICH A CONTINUATION OR RENEWAL REQUEST IS REQUIRED TO BE SUBMITTED FOR BOARD APPROVAL.

ANY MODIFICATIONS TO APPROVED PROJECT MUST ALSO BE SUBMTTTED FOR APPROVAL.

Comments, Modifications/Conditions for Approval or Reasons for Deferral or Disapproval are as follows:

Signature:

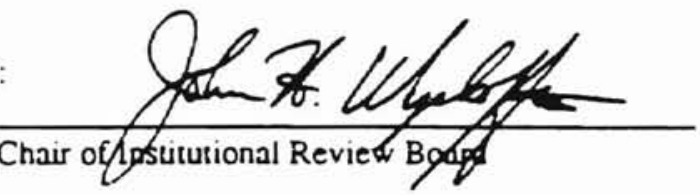

Date: July 19. 1995 

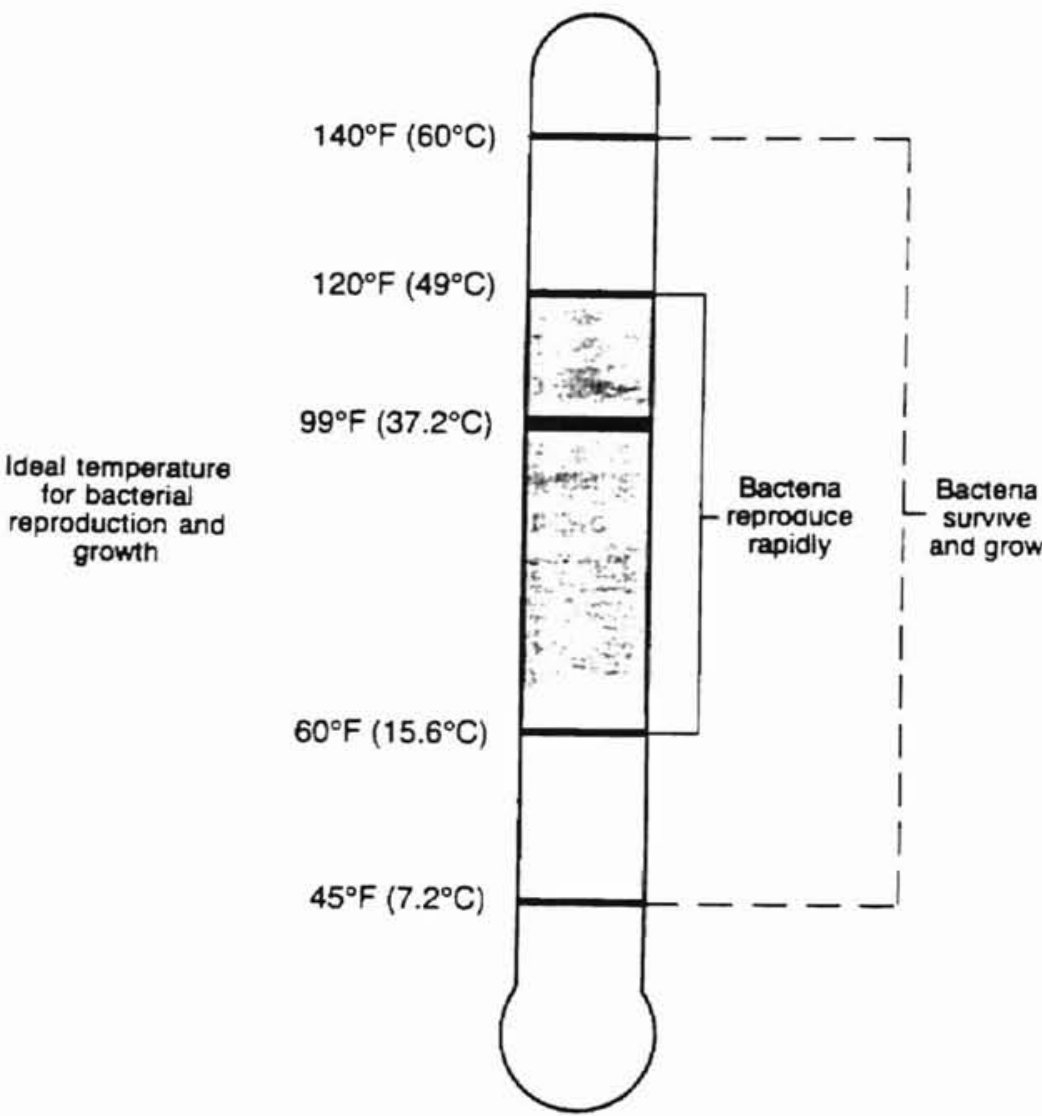

Temperature Danger Zone

(Byers et al., 1994 p. 3(1) 
APPENDIX D

MICROBIOLOGICAL HAZARDS 


\section{Hazardous Microorganisms and Parasites Grouped on the Basis of Risk Severitya}

\section{Severe Hazards}

Clostridium botulinum types A, B, E, and F

Shigella dysenteriae

Salmonella typhi; paratyphi A, B

Hepatitis A and E

Brucella abortis; B. suis

Vibrio cholerae 01

Vibrio vulnificus

Taenia solium

Trichinella spiralis

\section{Moderate Hazards: Potentially Extensive Spread ${ }^{b}$}

Listeria monocytogenes

Salmonella spp.

Shigella spp.

Enterovirulent Escherichia coli (EEC)

Streptococcus pyogenes

Rotavirus

Norwalk virus group

Entamoeba histolytica

Diphyllobothrium latum

Ascaris lumbricoides

Cryptosporidium parvım

\section{Moderate Hazards: Limited Spread}

Bacillus cereus

Campylobacter jejuni

Clostridium perfringens.

Staphyloccoccus aureus

Vibrio cholerae, non-()1

Vibrio parahaemolyticus

Yersinia enterocolitica

Giardia lamblia

Taenia saginata

a Adapted from International Commission on Microbiolobical Specilications for Food (ICMSF) (1986)

$\mathrm{b}$ Although classified as moderate hazards, complications and sequelac may he severe in certain susceptible populations.

Figure 2: Hazardous Microorganisms, 1995 Food Code, p. HACCP 6 \& 7 
APPENDIX E

PRINCIPLES OF HACCP 


\section{PRINCIPLES OF HAZARD ANALYSIS AND CRITICAL CONTROL POINTS}

\section{PRINCIPLE \# 2}

IDENTIFY THE CRITICAL CONTROL POINTS (CCP) IN FOOD PREPARATION

PRINCIPLE \# 3

ESTABLISH CRITICAL LIMITS FOR PREVENTIVE MEASURES

\section{PRINCIPLE \# 4}

ESTABLISH PROCEDURES TO MONITOR CCPS

\section{PRINCIPLE \# 5}

ESTABLISH THE CORRECTIVE ACTION TO BE TAKEN WHEN MONITORING SHOWS THAT A CRITICAL LIMIT HAD BEEN EXCEEDED

\begin{tabular}{c} 
PRINCIPLE \# 6 \\
\hline ESTABLISH EFFECTIVE RECORD KEEPING SYSTEMS \\
THAT DOCUMENT THE HACCP SYSTEM
\end{tabular}

\begin{tabular}{|c|}
\hline PRINCIPLE \# 7 \\
ESTABLISH PROCEDURES TO VERIFY THAT \\
THE HACCP SYSTEM IS WORKING \\
\hline
\end{tabular}


APPENDIX F

CCP DECISION TREE 


\section{Critical Control Point Decision Tree}

(Apply at each step in food preparation that has an ıdentified hazard)

Q 1. Do preventive measure(s) exist for the identified hazard?

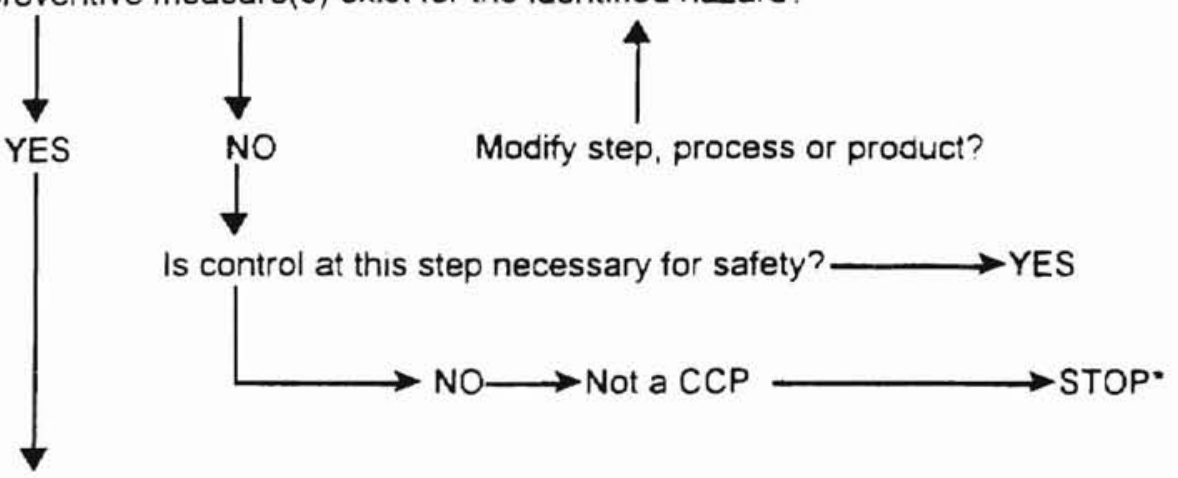

$Q$ 2. Does this step eliminate or reduce the likely occurrence of a hazard to an acceptable level?

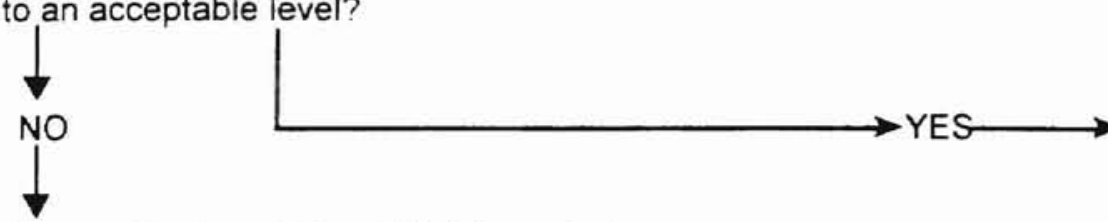

Q 3 Could contamination with identified hazard(s) occur in excess of acceptable level(s) or could these increase to unacceptable level(s)?

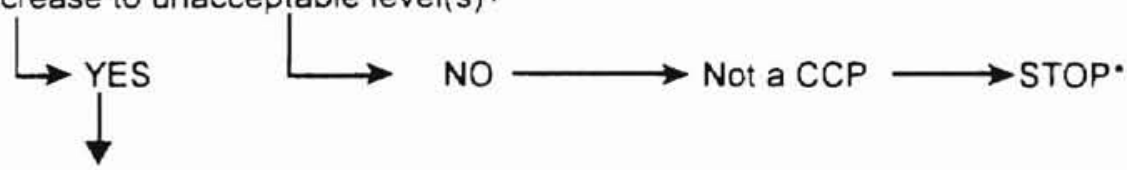

Q 4 Will a subsequent step elimınate identified hazard(s) or reduce the likely occurrence to an acceptable level?
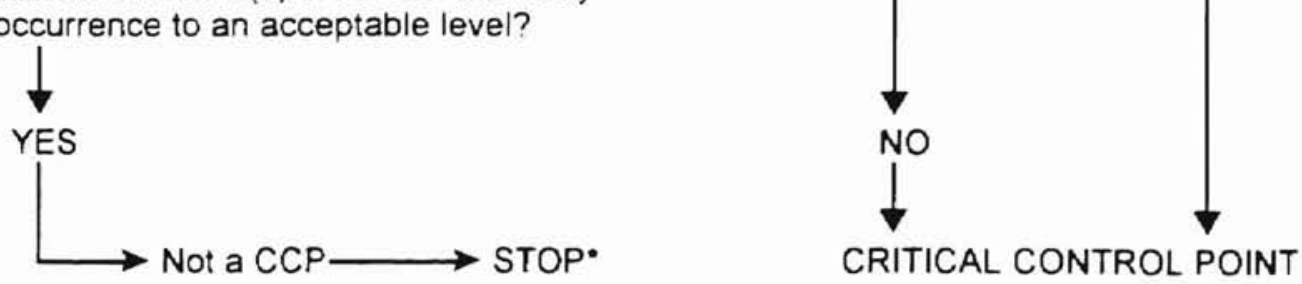

*PROCEED TO NEXT STEP IN THE DESCRIBED PROCESS

1995 Food Code p. HACCP 15 
APPENDIX G

RAW DATA 
TABLE $\mathbf{X}$

Attitudinal Responses Toward Food Safety Practices

\section{Statements}

Correct

Incorrect

Not Sure

No Response

Total

1. When I am at work preparing food, I always wear a clean apron and clean clothes. Agree

0 $0 \%$ 0

0

68 $100 \%$

2. Food handlers may smoke in food preparation and service areas. Disagree

$\begin{array}{lllll}65 & 1 & 1 & 1 & 68 \\ 95.5 \% & 1.5 \% & 1.5 \% & 1.5 \% & 100 \%\end{array}$

3. I believe that frequent and thorough handwashing is very important in keeping food safe to eat. Agree

$\begin{array}{lllll}68 & 0 & 0 & 0 & 68 \\ 100 \% & 0 \% & 0 \% & 0 \% & 100 \%\end{array}$

4 I always wear a hair restraint (hairnet or cap) when preparing food at work. Agree

$\begin{array}{lllll}67 & 1 & 0 & 0 & 68 \\ 98.5 \% & 1.5 \% & 0 \% & 0 \% & 100 \%\end{array}$

$5 \mathrm{I}$ believe that a sanitizing agent should be used to clean the surfaces on which I prepare both raw and cooked food Agree

$\begin{array}{lllll}62 & 2 & 1 & 3 & 68 \\ 91 \% & 3 \% & 1.5 \% & 4.5 \% & 100 \%\end{array}$




\title{
Statements
}

6. It is okay to thaw frozen food on the kitchen counter prior to

\author{
preparation. Disagree
}

61

$90 \%$

4

$6 \%$

2

1

7. I can tell by my nose or taste when a food item would make a person sick. Disagree
27 $40 \%$

$\begin{array}{ll}29 & 36 \\ 43 \% & 53 \%\end{array}$

$1 \%$

2

$3 \%$

$1 \%$

$100 \%$

8 Hot foods should be cooled to room temperature before being placed in the refrigerator. Disagree

$\begin{array}{ll}63 & 3 \\ 93 \% & 4 \%\end{array}$
$3 \%$ 2 $3 \%$ 0 a necessary tool in making sure

10 In order to prevent foodborne illness, previously cooked foods such as meat or poultry should be thoroughly reheated to $165^{\circ} \mathrm{F}$ or higher. Agree $100 \%$ $100 \%$

57
$84 \%$

5

$6 \%$

0 $0 \%$ 
11. When I am in doubt about the safety of a previously cooked food,

I throw it out rather than serve it. Agree 63

$$
93 \%
$$

4

$6 \%$

$\begin{array}{lll}68 & 0 & 0 \\ 100 \% & 0 \% & 0 \%\end{array}$

$0 \%$

$0 \%$

13. The depth of the container is important when placing hot food in the refrigerator to be cooled. Agree

\section{3} $78 \%$ 4 $6 \%$

\section{0} $15 \%$

1

14. When the room temperature is $90^{\circ} \mathrm{F}$. or above, cooked food should not be left out longer than one (1) hour before reheating or refrigerating or freezing. Agree

52
52
$76 \%$ 7 9 0

15. I prepare and serve the food here at work in the same manner I prepare and serve food at my home Disagree

$\begin{array}{lllll}14 & 50 & 2 & 2 & 68 \\ 20.5 \% & 73.5 \% & 3 \% & 3 \% & 100 \% \\ & & & & \\ 68 & 0 & 0 & 0 & 68 \\ 100 \% & 0 \% & 0 \% & 0 \% & 100 \%\end{array}$

16 I think it is important for foodservice workers to have a tuberculosis skin test Agree $0 \%$ $0 \%$ 


\section{Statements}

\section{Correct}

Incorrect

Not Sure

No Response

Total

17. I do not combine leftover food with fresh food. Agree

18. I know what the letters HACCP represent. Agree

$96 \% \quad 3 \%$

1

29

$43 \%$

7

29

$43 \%$

$4 \%$

68

19. Ground beef should be cooked to a temperature of $150^{\circ} \mathrm{F}$

$$
\text { Disagree }
$$

21 $31 \%$

25

$37 \%$

16

6

Agree Disagree

20. I have had training about avoiding and $F$. coli outbreak depends

$\begin{array}{ll}31 & 16 \\ 46 \% & 23.5 \%\end{array}$

16
5

21. I do not eat food during preparation or service except to taste appropriately.

$$
\text { Agree }
$$
$96 \%$

2 $3 \%$

$1 \%$ $0 \%$ 
TABLE XI

Knowledge of Food Safety Responses

\begin{tabular}{llllll} 
& Correct & Incorrect & Not Sure & No Response & Total \\
\hline $\begin{array}{l}\text { 1. Hot foods should be kept above } \\
140^{\circ} \mathrm{F} \text { and cold foods below }\end{array}$ & & & & & \\
$45^{\circ} \mathrm{F}$. True & 43 & 12 & 9 & 4 & 68 \\
& $63 \%$ & $18 \%$ & $13 \%$ & $6 \%$ & $100 \%$
\end{tabular}

2. You should keep raw meat, poultry eggs or fish separate from cooked foods during preparation. True

$\begin{array}{lllll}66 & 0 & 0 & 2 & 68 \\ 97 \% & 0 & 0 & 3 \% & 100 \%\end{array}$

3. You should prepare salads containing meat, poultry, eggs, or fish with pre-cooled ingredients whenever possible True

$72 \%$

$9 \%$

7

68

4. Cooked foods can be held at room temperature for more than 3 hours because the bacteria have been killed during cooking

$\begin{array}{cllll}4 & 55 & 6 & 3 & 68 \\ 6 \% & 81 \% & 9 \% & 4 \% & 100 \%\end{array}$


5. Dishes should be washed, rinsed and sanitized, but kitchen equipment (such as slicers and grinders) only need to be wiped off with a damp sponge or cloth. 5 $7 \%$ 60 2 68

6. The maximum height of pans used to cool and store food in refrigerators should be not more than

$\begin{array}{lllll}34 & 5 & 25 & 4 & 68 \\ 50 \% & 7 \% & 37 \% & 6 \% & 100 \% \\ 41 & 20 & 4 & 3 & 68 \\ 60 \% & 29 \% & 6 \% & 4 \% & 99 \%\end{array}$

7. Frozen foods should be received and stered at: $3 \%$

2 $3 \%$

9 How often should a food handler wash his or her hands?
57 $84 \%$
9 $13 \%$ $15 \%$ $1.5 \%$ $1.5 \%$

68 $100 \%$

10. When handling cooked foods you should

\begin{tabular}{l}
64 \\
$94 \%$ \\
\hline
\end{tabular}

$1.5 \%$

3

68 $99.5^{\circ} \circ$

0
0


VITA

Mary S. Callison, RD, LD

Candidate for the Degree of

Master of Science

Thesis: THE CHALLENGE OF FOOD SAFETY FOR HEAD START PERSONNEL

Major Field: Nutritional Sciences

Biographical:

Personal Data: Born in Manhattan, Kansas, August 26, 1955, daughter of Hugh and Juanita Robinson, raised in Woodward, Oklahoma, married Glenn Callison on January 15, 1975.

Education: Graduated from Woodward High School, Woodward, Oklahoma in May, 1973; attended Northwestern State College in Alva, Oklahoma from 1973 to 1974; received Bachelor of Science degree from Oklahoma State University in Stillwater, Oklahoma in December, 1977; completed Approved Pre-Professional Practice program in December, 1994 from Oklahoma State University; passed registration examination to meet requirements for American Dietetic Association active membership in April, 1995; completed requirements for the Master of Science degree at Oklahoma State University in July, 1996.

Professional Experience: Director of Elderly Nutrition Program, Pawnee Tribe, November, 1980 to June, 1981 and October, 1982 to September, 1985; Project Director, Northwest Oklahoma Senior Citizens Nutrition Council, December, 1985 to July, 1988; Project Director, Wheatheart Nutrition Project, July, 1988 to June, 1994; Consultant Dietitian Head Start, January, 1995 to September, 1995; Food and Nutrition Services Director, Edmond Regional Medical Center, October, 1995 to December, 1995; Consultant Dietitian, long-term care facilities, August, 1995 to present; Clinical Dietitian, St. Joseph's Regional Medical Center, Ponca City, Oklahoma.

Professional Organizations: American Dietetics Association, Oklahoma Dietetic Association, Consultant Dietitians in Health Care Facilities Practice Group, Sports, Cardiovascular and Wellness Nutritionists Practice Group, Society for Nutrition Education, Oklahoma Consultant Dietitians in Health Care Facilities. 